\title{
COMPARISONS OF WATER QUALITY DURING VARIOUS STREAMFLOW CONDITIONS IN FIVE STREAMS IN NORTHERN NEW JERSEY, 1982-97
}

Water-Resources Investigations Report 01-4249

Prepared in cooperation with the DELAWARE RIVER BASIN COMMISSION

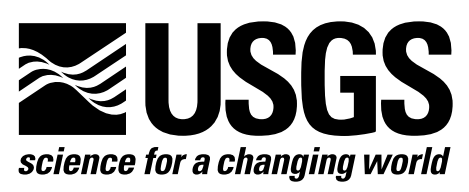




\section{COMPARISONS OF WATER QUALITY DURING VARIOUS STREAMFLOW CONDITIONS IN FIVE STREAMS IN NORTHERN NEW JERSEY, 1982-97}

By Kathryn Hunchak-Kariouk

U.S. GEOLOGICAL SURVEY

Water-Resources Investigations Report 01-4249

Prepared in cooperation with the DELAWARE RIVER BASIN COMMISSION

West Trenton, New Jersey

2002






\title{
U.S. DEPARTMENT OF THE INTERIOR \\ GALE A. NORTON, Secretary
}

\author{
U.S. GEOLOGICAL SURVEY
}

Charles G. Groat, Director

For additional information write to:

District Chief

U.S Geological Survey

Mountain View Office Park

810 Bear Tavern Road

West Trenton, NJ 08628
Copies of this report can be purchased from:

U.S. Geological Survey

Branch of Information Services

Box 25286

Denver, CO 80225-0286 


\section{CONTENTS}

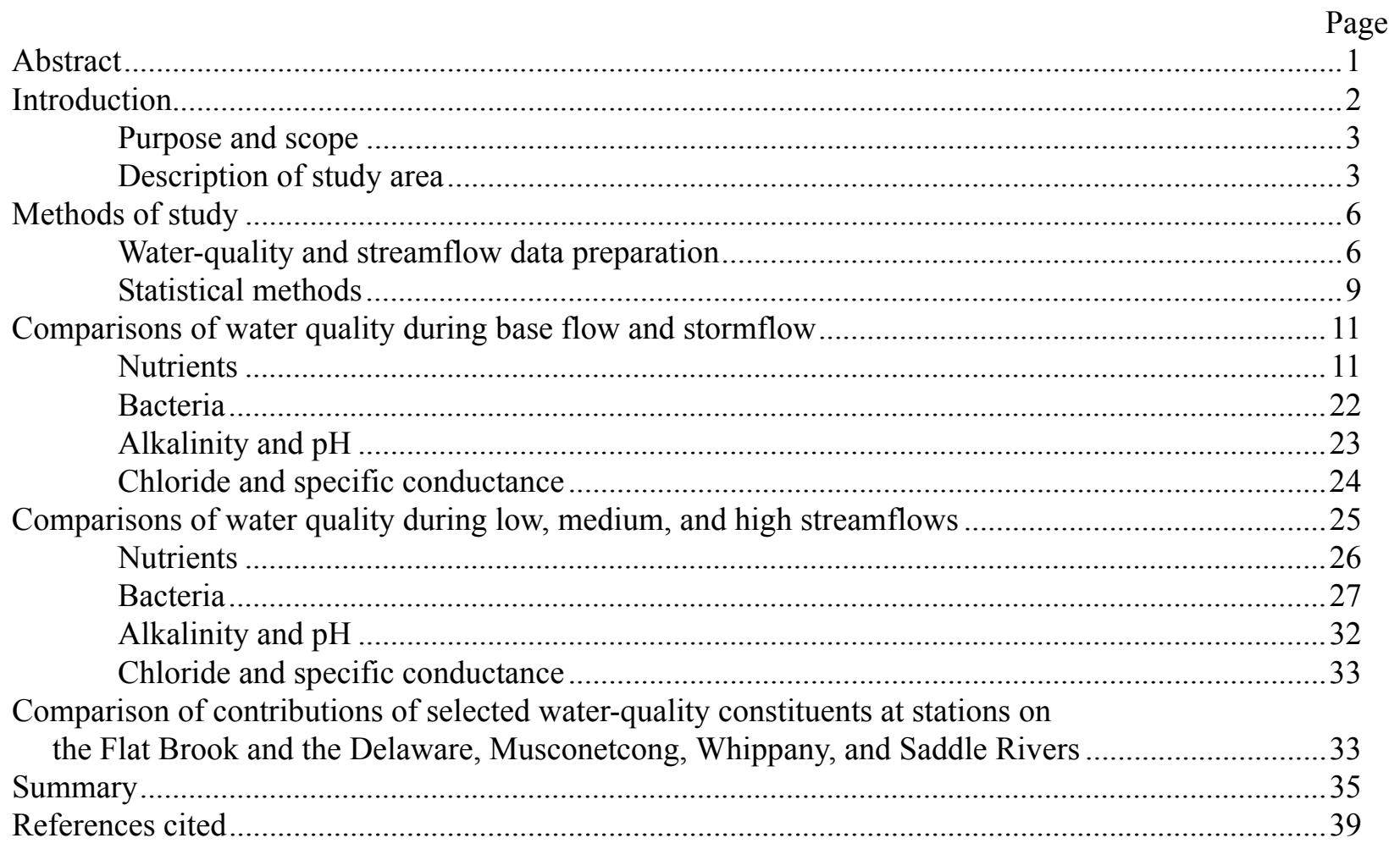

\section{ILLUSTRATIONS}

Figure 1. Locations of water-quality and streamflow-gaging stations on the Flat Brook and the Delaware, Musconetcong, Whippany, and Saddle Rivers, New Jersey ..............................4

2. Schematic design of a storm hydrograph.

3. Graph showing the number of samples collected at stations on the Flat Brook and the Delaware, Musconetcong, Whippany, and Saddle Rivers, N.J., by flow duration and type of flow, water years 1982-97

4. Graph showing flow-duration curves for water-quality stations with continuous streamflow records on the Flat Brook and the Delaware, Musconetcong, Whippany, and Saddle Rivers, New Jersey, period of record through 1997.

5. Boxplots showing concentrations of selected water-quality constituents in samples collected before, during, and after a storm at water-quality stations on the Flat Brook and the Delaware, Musconetcong, Whippany, and Saddle Rivers, N.J., water years 1982-97

6. Boxplots showing yields of selected water-quality constituents in samples collected before, during, and after a storm at water-quality stations on the Flat Brook and the Delaware, Musconetcong, Whippany, and Saddle Rivers, N.J., water years 1982-97.

7. Boxplots showing concentrations of selected water-quality constituents in samples collected during low, medium, and high flows at water-quality stations on the Flat Brook and the Delaware, Musconetcong, Whippany, and Saddle Rivers, N.J., water years 1982-97. 


\section{ILLUSTRATIONS--Continued}

Figure 8. Boxplots showing yields of selected water-quality constituents in samples collected during low, medium, and high flows at water-quality stations on the Flat Brook and the Delaware, Musconetcong, Whippany, and Saddle Rivers, N.J., water years 1982-97

\section{TABLES}

Table 1. Description of and period of record for selected stations on the Flat Brook and the Delaware, Musconetcong, Whippany, and Saddle Rivers, New Jersey

2. Estimated flow-duration values for water-quality stations on the Flat Brook and the Delaware, Musconetcong, Whippany, and Saddle Rivers, New Jersey, water years 1982-97

3. Results of the Tukey test to determine statistical differences for constituent concentrations and yields among samples collected at water-quality stations on the Flat Brook and the Delaware, Musconetcong, Whippany, and Saddle Rivers, New Jersey, during various streamflow conditions, water years 1982-97

4. Median concentrations and yields of selected constituents and results of the Tukey and Kruskal-Wallis tests to determine statistical differences between samples collected during base flow and stormflow at each water-quality station on the Flat Brook and the Delaware, Musconetcong, Whippany, and Saddle Rivers, New Jersey, water years 1982-97

5. Median concentrations and yields of selected constituents and results of the Tukey and Kruskal-Wallis tests to determine statistical differences among samples collected before, during, and after a storm at each water-quality station on the Flat Brook and the Delaware, Musconetcong, Whippany, and Saddle Rivers, New Jersey, water years 1982-97

6. Median concentrations and yields of selected constituents and results of the Tukey and Kruskal-Wallis tests to determine statistical differences among samples collected during low, medium, and high streamflows at each water-quality station on the Flat Brook and the Delaware, Musconetcong, Whippany, and Saddle Rivers, New Jersey, water years 1982-97. 


\section{CONVERSION FACTORS, VERTICAL DATUM, AND ABBREVIATED WATER-QUALITY UNITS}

Multiply

inch (in.)

mile (mi)

acre

square mile $\left(\mathrm{mi}^{2}\right)$

square mile $\left(\mathrm{mi}^{2}\right)$

gallon (gal)

gallon (gal)

cubic foot $\left(\mathrm{ft}^{3}\right)$

cubic foot per second $\left(\mathrm{ft}^{3} / \mathrm{s}\right)$

cubic foot per second per square mile $\left[\left(\mathrm{ft}^{3} / \mathrm{s}\right) / \mathrm{mi}^{2}\right]$

pound, avoirdupois (lb)

degree Fahrenheit $\left({ }^{\circ} \mathrm{F}\right)$

degree Celsius
By

Length

$$
25.4
$$

1.609

$\underline{\text { Area }}$

0.4047

259.0

2.590

\section{Volume}

3.785

0.003785

0.02832

Flow

0.02832

0.01093

$\underline{\text { Mass }}$

0.4536

Temperature

${ }^{\circ} \mathrm{C}=5 / 9 \times\left({ }^{\circ} \mathrm{F}-32\right)$

$\left({ }^{\circ} \mathrm{C}\right)^{\circ} \mathrm{K}=273.15+{ }^{\circ} \mathrm{C}$ $\underline{\text { To obtain }}$

millimeter

kilometer

hectare

hectare

square kilometer

liter

cubic meter

cubic meter

cubic meter per second cubic meter per second per square kilometer

kilogram

degree Celsius $\left({ }^{\circ} \mathrm{C}\right)$

degree Kelvin $\left({ }^{\circ} \mathrm{K}\right)$

Sea level: In this report "sea level" refers to the National Geodetic Vertical Datum of 1929-- a geodetic datum derived from a general adjustment of the first-order level nets of the United States and Canada, formerly called Sea Level Datum of 1929.

Water-quality abbreviations:

mg -milligrams

$\mathrm{mg} / \mathrm{L} \quad$-milligrams per liter

$\mu \mathrm{S} / \mathrm{cm} \quad$-microsiemens per centimeter

$(\mathrm{lb} / \mathrm{d}) / \mathrm{mi}^{2} \quad$ - pounds per day per square mile
MPN/100mL - most probable number of bacteria per 100 milliliters

$(\mathrm{MPN} / \mathrm{d}) / \mathrm{mi}^{2}$ - most probable number per day per square mile 


\title{
COMPARISONS OF WATER QUALITY DURING VARIOUS STREAMFLOW CONDITIONS IN FIVE STREAMS IN NORTHERN NEW JERSEY, 1982-97
}

\author{
By Kathryn Hunchak-Kariouk
}

\begin{abstract}
Relations between water-quality and flow characteristics and the relative importance of constant (point sources and ground-water discharge) and intermittent (nonpoint storm runoff) sources were determined for eight water-quality stations located on the Flat Brook and the Delaware, Musconetcong, Whippany, and Saddle Rivers. Waterquality and streamflow data were categorized on the basis of streamflow at the time of sample collection. Differences in concentrations and yields of selected water-quality constituents, including nutrients and bacteria, (1) among the stations during eight streamflow conditions and (2) at each station (a) between base flow and stormflow; (b) among before, during, and after a storm; and (c) among low, medium, and high flows were determined and related to the predominant type(s) of land development in the areas contributing drainage.
\end{abstract}

At the station on the Delaware River, yields of fecal-coliform bacteria were affected more by contributions from storm runoff than by contributions from point sources and ground-water discharges; yields during a storm $\left[7.0 \times 10^{8}\right.$ (MPN/d) $\mathrm{mi}^{2}$ (most probable number per day per square mile)] were greater than yields during base flow $\left(3.7 \times 10^{8}(\mathrm{MPN} / \mathrm{d}) \mathrm{mi}^{2}\right)$. Yields of nitrate plus nitrite, alkalinity, and chloride were affected more by contributions from point sources and ground-water discharges than by contributions from storm runoff; yields of these constituents were not significantly different during base flows and stormflows.

At the Flat Brook and Whippany River stations, yields of most water-quality constituents were affected more by contributions from storm runoff than by contributions from point sources and ground-water discharge. For example, yields of nitrate plus nitrite were greater during stormflow $\left(1.20(\mathrm{lb} / \mathrm{d}) / \mathrm{mi}^{2}\right.$ (pounds per day per square mile) and $15.88(\mathrm{lb} / \mathrm{d}) / \mathrm{mi}^{2}$, respectively) than during base flow $\left(0.26(\mathrm{lb} / \mathrm{d}) / \mathrm{mi}^{2}\right.$ and $8.20(\mathrm{lb} / \mathrm{d}) / \mathrm{mi}^{2}$, respectively).

At the Musconetcong River station, yields of total nitrogen, alkalinity, and chloride were affected more by contributions from storm runoff than by contributions from point sources and ground-water discharge. At three of the four water-quality stations on the Musconetcong River, yields of total phosphorus and bacteria were affected less by contributions from storm runoff than by contributions from point sources and ground-water discharge.

At the Saddle River station, yields of alkalinity and chloride were affected more by contributions from storm runoff than by contributions from point sources and ground-water discharge; for example, yields of chloride during stormflows (707 $\left.(\mathrm{lb} / \mathrm{d}) / \mathrm{mi}^{2}\right)$ were greater than during base flows $\left(401(\mathrm{lb} / \mathrm{d}) / \mathrm{mi}^{2}\right)$. Yields of total phosphorus were affected less by contributions from storm runoff than by contributions from point sources and ground-water discharge; yields during base flows $\left(4.00(\mathrm{lb} / \mathrm{d}) / \mathrm{mi}^{2}\right)$ and stormflows $\left(4.67(\mathrm{lb} / \mathrm{d}) / \mathrm{mi}^{2}\right)$ were similar.

Concentrations and yields of total phosphorus and nitrogen, and nitrate plus nitrite were strongly related to the amount of development in each drainage basin. At stations on the Saddle and Whippany Rivers, which drain areas with substantial development, concentrations and yields for all streamflow categories were higher than at stations on the Flat Brook and Delaware River, which drain areas with little development. Results of the Tukey test indicate that there are significant differences in total phosphorus concentrations at Saddle River and Flat Brook during base flows $(0.77 \mathrm{mg} / \mathrm{L}$ (milligrams per liter) and $0.02 \mathrm{mg} / \mathrm{L}$, respectively) and stormflows $(0.42 \mathrm{mg} / \mathrm{L}$ and $0.02 \mathrm{mg} / \mathrm{L}$, respectively). 


\section{INTRODUCTION}

The Delaware River Basin commission (DRBC), the New Jersey Department of Environmental Protection (NJDEP), and other Federal, State, and local agencies in New Jersey have initiated a number of water-quality programs to address nonpoint-source issues of water quality in streams in the State. Traditionally, the goals and objectives of these programs have been oriented to base-flow conditions as represented by minimum average 7consecutive-day low-flow conditions. Sources and mode of transport of water-quality constituents, such as nutrients and bacteria, to streams, as well as the streamflow conditions, can affect instream concentrations and loads of constituents that are transported by streams to receiving water bodies. Water managers cannot rely solely on concentration-based water-quality criteria derived from lowflow, non-runoff conditions when designing management strategies to reduce high streamflow and storm runoff (Richard Albert, Delaware River Basin Commission, oral commun., 1998).

Instream concentrations of constituents are the result of contributions from point and nonpoint sources that are transported to a river in direct discharge, ground-water discharge, and storm runoff, which then are modified by instream physical, biological, and chemical processes. Point sources are discrete, identifiable origins of constituents, such as permitted discharges from municipal- and industrial-wastewater-treatment facilities, that discharge water directly into streams and contribute constituents to a stream at a relatively constant rate, independent of streamflow conditions. Ground-water discharge can contribute constituents at a relatively constant rate to a stream from diffuse, nonpoint sources because it can contain infiltrated water and effluent from leaking septic systems, undergroundstorage tanks, and landfills. Fractured-rock zones will affect the ground-water flow at specific locations in the study area, especially during runoff events. Nonpoint-source runoff associated with stormwater and snowmelt can contribute constituents from urban, agricultural, and other developed areas to a stream intermittently, depending on runoff and storm intensity.
Constituents from diffuse, nonpoint sources (NPS) are transported to a stream in ground-water discharge and by storm runoff. NPS contributions are affected greatly by the type and intensity of development and historical land use in the contributing drainage areas. Storm runoff can contribute NPS constituents, such as roadway deicing salts, lawn and farm fertilizers, and pesticides, animal wastes, and other constituents, to a stream. Increases in the amount of impervious land surfaces in a highly developed and urbanized watershed affect the extent and intensity of NPS contributions by reducing the infiltration rate of rainfall and causing runoff that alters the channel and riparian characteristics of the stream (Rosgen, 1996). Undeveloped areas with forest plus wetlands land use have higher water retention and less storm runoff as a result of ponding and dense vegetation than areas with some type of development (Johnsson and Barringer, 1993). The concentrations of some constituents can remain high for many years in streams that receive contributions of older ground water (with residence time on the order of many years to many decades), which contains constituents attributed to historical land uses. Past land-use activity, particularly agriculture, can result in long-term modifications to and reductions in aquatic diversity, regardless of reforestation of riparian zones (Harding and others, 1998).

Instream constituent concentrations are a summation of the contributions from constant (point sources and ground-water discharge) and intermittent (storm runoff) sources, and will vary greatly with streamflow. The relative importance of contributions of constituents from NPS storm runoff and from point sources and ground-water discharge can be assessed by comparing concentrations and area-normalized loads (yields) over a range of streamflow conditions. Relations between concentration and streamflow are difficult to evaluate because contributions from storm runoff are flow dependent; a low concentration can represent a high instream load during high-flow conditions. The use of loads (mass per time) instead of concentration (mass per volume) removes the effect of changing streamflow (volume per time). Yields (loads normalized to the basin area) determined for various stations are directly comparable. 
The manner by which constituents are transported to a stream (relatively constant-rate point-source and ground-water discharge, or intermittent-rate storm runoff) and the streamflow condition of the river affect the amount of constituents transported by the river at any one time (Price and Schaeffer, 1995; Buxton and others, 1998; Buxton and others, 1999). Whereas instream concentrations of constituents contributed to a stream by way of storm runoff might decrease during runoff conditions (stormflows, during a storm, and high flows), yields of these constituents will most likely be higher during runoff conditions than non-runoff conditions (base flows, before a storm, and low flows). The discharge rate and concentrations of constituents in point-source and ground-water discharges generally remain constant during changing streamflow conditions. Whereas the instream concentration of constituents from point sources and ground-water discharge will most likely decrease during runoff conditions, yields most likely will be similar during runoff and non-runoff conditions.

The U.S. Geological Survey (USGS), in cooperation with the DRBC, conducted a study to examine and develop methods to compare-water quality and streamflow characteristics at selected sites and to evaluate watershed-based NPS assessment methods. The overall study was divided into two parts. The DRBC assessed the individual stream sites and basins of the study area by conducting physical and biological surveys of the streambeds and banks and determining the amount of land development and the percentage of imperviousness within the basins. The USGS analyzed historical data to investigate how water quality varied with streamflow within each basin. Results of the watershed and stream analyses by the DRBC are presented separately (Albert and Limbeck, 2000). The water-quality assessments conducted by the USGS and the watershed-based assessments conducted by the DRBC can be combined to develop numerical and non-numerical criteria for selected constituents in high-flow storm runoff to surface waters.

\section{Purpose and Scope}

This report presents a summary of historical water-quality data collected during baseflow, during stormflow, before a storm, during a storm, after a storm, and during low, medium, and high flows. The data were used to determine relations between water quality and flow characteristics for watersheds of various sizes and with various predominant types of land development. For the purpose of this report, water quality is described by values of concentration and yield; flow characteristics are described by streamflow values. This report presents comparisons of water quality during various streamflow conditions at eight waterquality stations on five streams in northern New Jersey during ${ }^{1}$ water years 1982-97. Distributions of constituent concentrations and yields are presented in figures. Results of tests for statistical differences in concentrations and yields are listed in tables.

\section{Description of Study Area}

The study area comprises the drainage areas of eight water-quality monitoring stations located on the Flat Brook and the Delaware, Musconetcong, Whippany, and Saddle Rivers in northern New Jersey (fig. 1). The stations were selected on the basis of the availability of water-quality and streamflow data and generalizations about the type of land development in the areas contributing drainage (table 1). Land development ranged from mostly undeveloped (Flat Brook at Flatbrookville) to highly developed (Saddle River at Lodi). Point sources include permitted municipal, industrial, and commercial wastewater discharge facilities located upstream from stations on the Saddle, Whippany, and Musconetcong Rivers. Streamflow in the Delaware River is greatly affected by releases from water-supply and power-generating reservoirs in the upper part of the watershed. Pointsource discharges to the Delaware River upstream from the station at Montague are minor (a small municipal sewage-treatment plant discharges at Point Jervis, New York, just upstream from the station).

\footnotetext{
${ }^{1} \mathrm{~A}$ water year is the 12-month period from October 1 through September 30 and is designated by the calendar year in which it ends.
} 


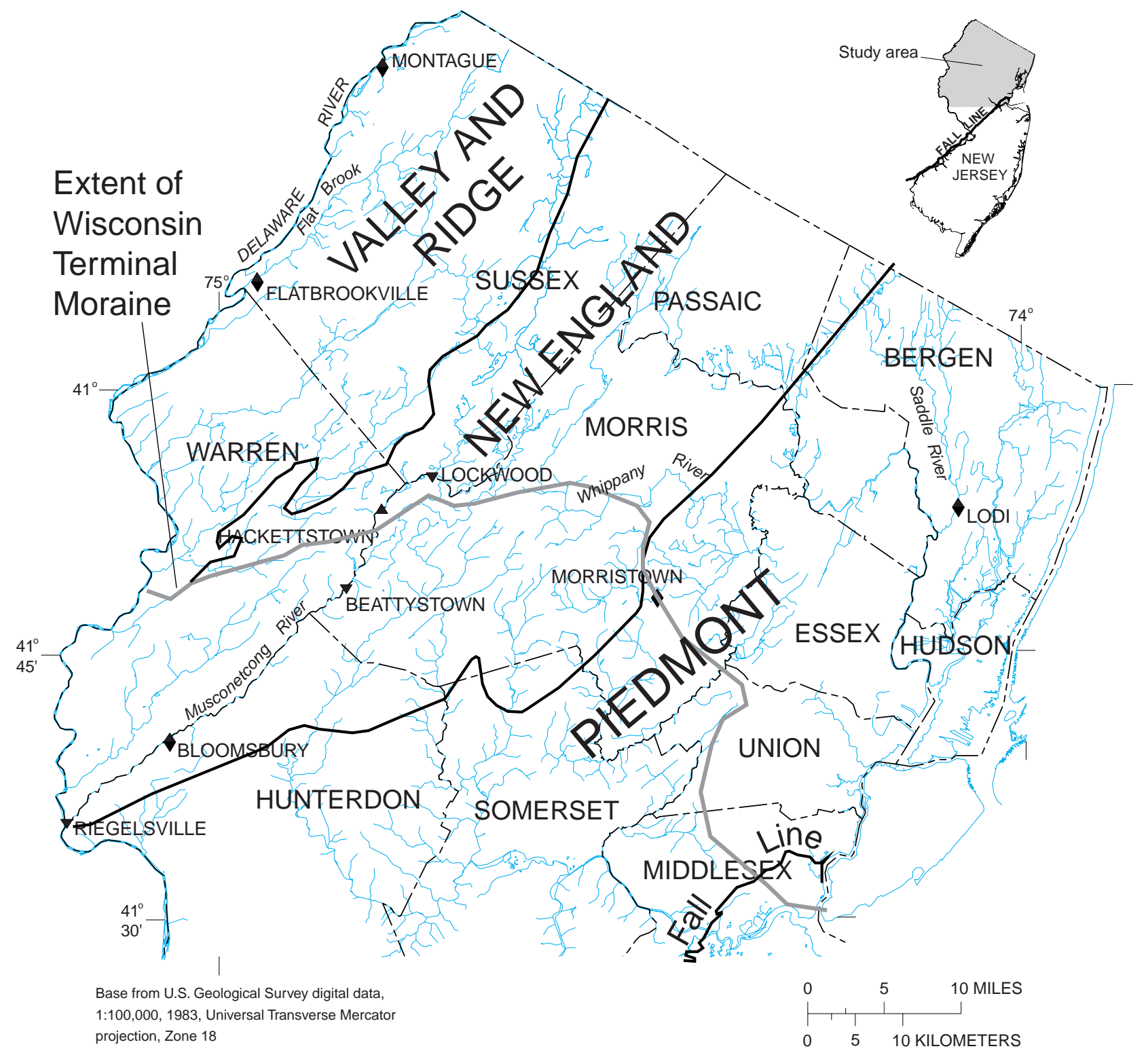

\section{EXPLANATION}

- Streamflow-gaging station

$\boldsymbol{\nabla}$ Water-quality station

$\checkmark$ Streamflow-gaging station and water-quality station

Figure 1. Locations of water-quality and streamflow-gaging stations on the Flat Brook and the Delaware, Musconetcong, Whippany, and Saddle Rivers, New Jersey. 
Table 1. Description of and period of record for selected stations on the Flat Brook and the Delaware, Musconetcong, Whippany, and Saddle Rivers, New Jersey

[Sites listed in order of increasing intensity of land development in the areas contributing drainage and in downstream order on the Musconetcong River; --, data not collected; ND, not determined]

\begin{tabular}{|c|c|c|c|c|c|c|}
\hline \multirow{2}{*}{$\begin{array}{c}\text { U.S. } \\
\text { Geological } \\
\text { Survey } \\
\text { station } \\
\text { number }\end{array}$} & \multirow[b]{2}{*}{ Station name and identifier } & \multirow{2}{*}{$\begin{array}{l}\text { Drain- } \\
\text { age } \\
\text { area, in } \\
\text { square } \\
\text { miles }\end{array}$} & \multirow[b]{2}{*}{ Land use } & \multirow[b]{2}{*}{$\begin{array}{c}\text { Imper- } \\
\text { viousness }{ }^{1}, \\
\text { in percent }\end{array}$} & \multicolumn{2}{|c|}{ Period of record (water years) } \\
\hline & & & & & $\begin{array}{c}\text { Daily } \\
\text { stream- } \\
\text { flow }\end{array}$ & Water quality \\
\hline 01438500 & Delaware River at Montague (DR) & 3,480 & $\begin{array}{l}\text { Mostly forested; some low-density } \\
\text { residential }\end{array}$ & ND & $1940-97$ & $1956-73,1976-78,1991-97$ \\
\hline${ }^{2} 01440000$ & Flat Brook at Flatbrookville (FB) & 64.0 & Mostly forested & 2.0 & 1923-97 & $\begin{array}{l}1923-24,1956-57,1959-80 \\
1993,1995,1997\end{array}$ \\
\hline 01455801 & Musconetcong River at Lockwood (MR1) & 60.1 & Urban & 8.5 & -- & $1976-91$ \\
\hline 01456000 & Musconetcong River near Hackettstown & 68.9 & ND & ND & $1922-73$ & -- \\
\hline${ }^{3} 01456200$ & Musconetcong River at Beattystown (MR2) & 90.3 & Residential & ND & -- & $1976-97$ \\
\hline${ }^{3} 01457000$ & Musconetcong River near Bloomsbury (MR3) & 141 & Agricultural and residential & 5.6 & $\begin{array}{l}1903-07 \\
1921-97\end{array}$ & $1963-80,1991-97$ \\
\hline 01457400 & Musconetcong River at Riegelsville (MR4) & 156 & Agricultural and low-density residential & 5.3 & -- & $1962,1976-97$ \\
\hline 01381500 & Whippany River at Morristown (WR) & 29.4 & $\begin{array}{l}\text { Half urban and half agricultural, parks, } \\
\text { and vacant land }\end{array}$ & 23 & $1921-97$ & $\begin{array}{l}1923-24,1926 \\
1962-97\end{array}$ \\
\hline${ }^{2} 01391500$ & Saddle River at Lodi (SR) & 54.6 & Urban and industrial & 29 & 1924-97 & $1962-97$ \\
\hline
\end{tabular}

${ }^{1}$ Data from Albert and Limbeck, 2000.

${ }^{2}$ Water quality has been monitored every other year since 1993.

${ }^{3}$ Water-quality monitoring discontinued after water year 1997. 
The Whippany and Saddle River watersheds are in the Piedmont Physiographic Province of New Jersey, and the Musconetcong River watershed is in the New England Physiographic Province (Fenneman, 1938; Ayers and Pustay, 1988). The stations on the Flat Brook and Delaware River are in the Valley and Ridge Physiographic Province.

To evaluate how streams of various sizes respond to high-flow runoff events, stations were selected to represent a range of watershed sizes. The station on the Delaware River at Montague drains an area of $3,480 \mathrm{mi}^{2}$, and the other stations drain relatively small areas that range from 29.4 to $156 \mathrm{mi}^{2}$. Streamflow data from the station on the Musconetcong River near Hackettstown were included to aid the evaluation of water-quality data at other stations on the Musconetcong River where daily streamflow data were not collected.

\section{METHODS OF STUDY}

This section describes the methods and criteria used for the preparation and analysis of the water-quality and streamflow data. The calculation of area-normalized instantaneous load values (referred to as yields) is described, as are the various statistical methods used for this analysis.

\section{Water-Quality and Streamflow Data Preparation}

Constituents analyzed were chosen on the basis of their usefulness as indicators of the quality of the surface water and in developing effective surface-water-quality management strategies. The constituents selected include nutrients (total phosphorus, nitrogen, and nitrate plus nitrite), fecalcoliform bacteria, alkalinity, $\mathrm{pH}$, chloride, and specific conductance.

Surface-water quality and instantaneous streamflow data for eight stations on five streams during water years 1982-97 (October 1, 1981, through September 30, 1997) were retrieved from WATSTORE (National Water Information System) (Hutchinson, 1975). The 16-year period of record was selected in order to have sufficient data for individual streamflow categories, especially data for storms. No significant trends (changes in water quality over time) were determined for the constituents during the study period, although statistically significant trends have been reported for some constituents for specific periods during water years 1982-97 (Hay and Campbell, 1990; Hickman and Barringer, 1999).

The date of each water-sample collection was identified and used to assign the data to categories on the basis of streamflow values. Available 15-minute streamflow data (referred to as unit data) for the six stations with continuous-streamflow records were supplemented with unit data for water years 1982-95 retrieved from archival storage on magnetic tape. For each water-quality sample-collection date at each station, the waterquality and streamflow values were assigned to (1) one of six categories that describe when during a storm samples were collected and (2) one of three categories that reflect the magnitude of the instantaneous streamflow compared to flow-duration values.

For each date of water-quality sampling at the five stations with continuous streamflow records (those on the Flat Brook; the Delaware, Whippany, and Saddle Rivers; and the Musconetcong River near Bloomsbury), unit data for a 7-day period ( 3 days prior to and after the sampling date, and the day of sampling) were plotted. The plots were examined to determine whether the samples were collected during a storm, and, if so, whether the streamflow at the time of sample collection was constant, increasing, or decreasing. For the stations with no continuous streamflow records (those on the Musconetcong River at Lockwood, Beattystown, and Riegelsville), streamflow data from nearby streamflow-gaging stations on the Musconetcong River near Hackettstown and Bloomsbury were used to determine whether the streamflow at the time of sample collection was constant, increasing, or decreasing.

For each water-quality sample-collection date at each station, the water-quality and streamflow values were categorized as occurring (1) during base flow (more than 3 days before or after a 
storm), (2) before a storm (within 3 days prior to a storm), (3) during rising streamflow (during the early part of a storm), (4) during peak stormflow, (5) during falling streamflow (during the end of a storm), or (6) after a storm (within 3 days after a storm) (fig. 2). For each station, the number of samples in each of these six categories was determined (fig. 3).

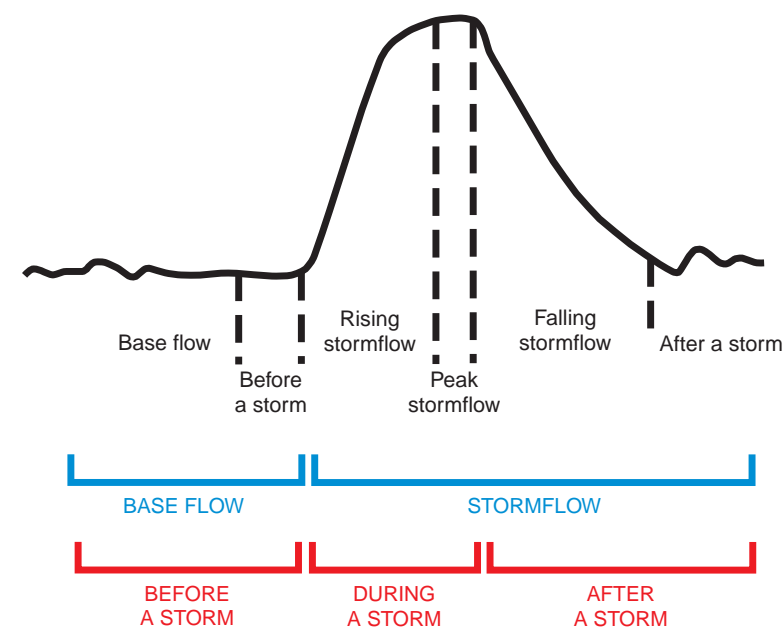

Figure 2. Schematic design of a storm hydrograph.

Flow-duration curves were developed by using the Daily Value Statistics (DVSTAT) computer program in the WATSTORE for the five stations with continuous streamflow records (fig. 4). Streamflow records from water years 1982-97 were used for flow-duration computations. Flowduration curves show the percentage of time that a particular discharge value would be equaled or exceeded at that station, and a flow-duration point is a discharge value, in cubic feet per second, interpolated from a duration table for a particular percentage of time (Searcy, 1959). Flow-duration values were determined for the stations on the Musconetcong River at Lockwood, Beattystown, and Riegelsville by using MOVE1 (Maintenance of Variance Extension, Type 1) (Hirsch, 1982) with the continuous streamflow records for the nearby streamflow-gaging stations on the Musconetcong River near Hackettstown and Bloomsbury. The 25-, 50-, and 75-percent flow duration values were determined for each of the eight stations (table 2).
For each water-quality sample-collection date at each station, the water-quality and streamflow values were categorized as low-, medium-, or high-flow samples according to the flow duration associated with the instantaneous streamflow at the time of sampling. Low-flow samples were those with streamflows equal to or less than the 75-percent flow-duration value; medium-flow samples were those with streamflows less than the 25-percent flow-duration value and higher than the 75percent flow-duration value; and high-flow samples were those with streamflows equal to or higher than the 25-percent flow-duration value. Values for low, medium, and high flows vary for each stream, depending on the size of the area contributing drainage. For example, at the station on the Delaware River (3,480- $\mathrm{mi}^{2}$ drainage area), low flows were equal to or less than $2,100 \mathrm{ft}^{3} / \mathrm{s}$, medium flows ranged from greater than 2,100 to less than $6,800 \mathrm{ft}^{3} / \mathrm{s}$, and high flows were equal to or greater than $6,800 \mathrm{ft}^{3} / \mathrm{s}$. At the station on the Whippany River (29.4- $\mathrm{mi}^{2}$ drainage area), low flows were equal to or less than $29 \mathrm{ft}^{3} / \mathrm{s}$, medium flows ranged from greater than 29 to less than $67 \mathrm{ft}^{3} / \mathrm{s}$, and high flows were equal to or greater than $67 \mathrm{ft}^{3} / \mathrm{s}$ (table 2 ). For each station, the number of samples in each of these three categories was determined (fig. 3).

Water-quality and streamflow data for each station were sorted for comparison into three groups on the basis of time of sample collection during a storm and magnitude of the streamflow at the time of sampling. Data were grouped according to sample collection (1) during base flow and stormflow; (2) before, during, and after a storm, depending on when the samples were collected (fig. 2); and (3) during low, medium, and high flows as a result of the comparison of the instantaneous streamflow to the 25- and 75-percent flowduration values for each station.

Data for samples collected during base flow or before a storm were classified as base flow for a comparison of water quality during base flow and stormflow, or before storm for a comparison of water quality before, during, and after a storm. For a comparison of water quality during base flow and stormflow, data for samples collected during rising, peak, or falling streamflow, or after a storm were classified as stormflow. For a comparison of water 


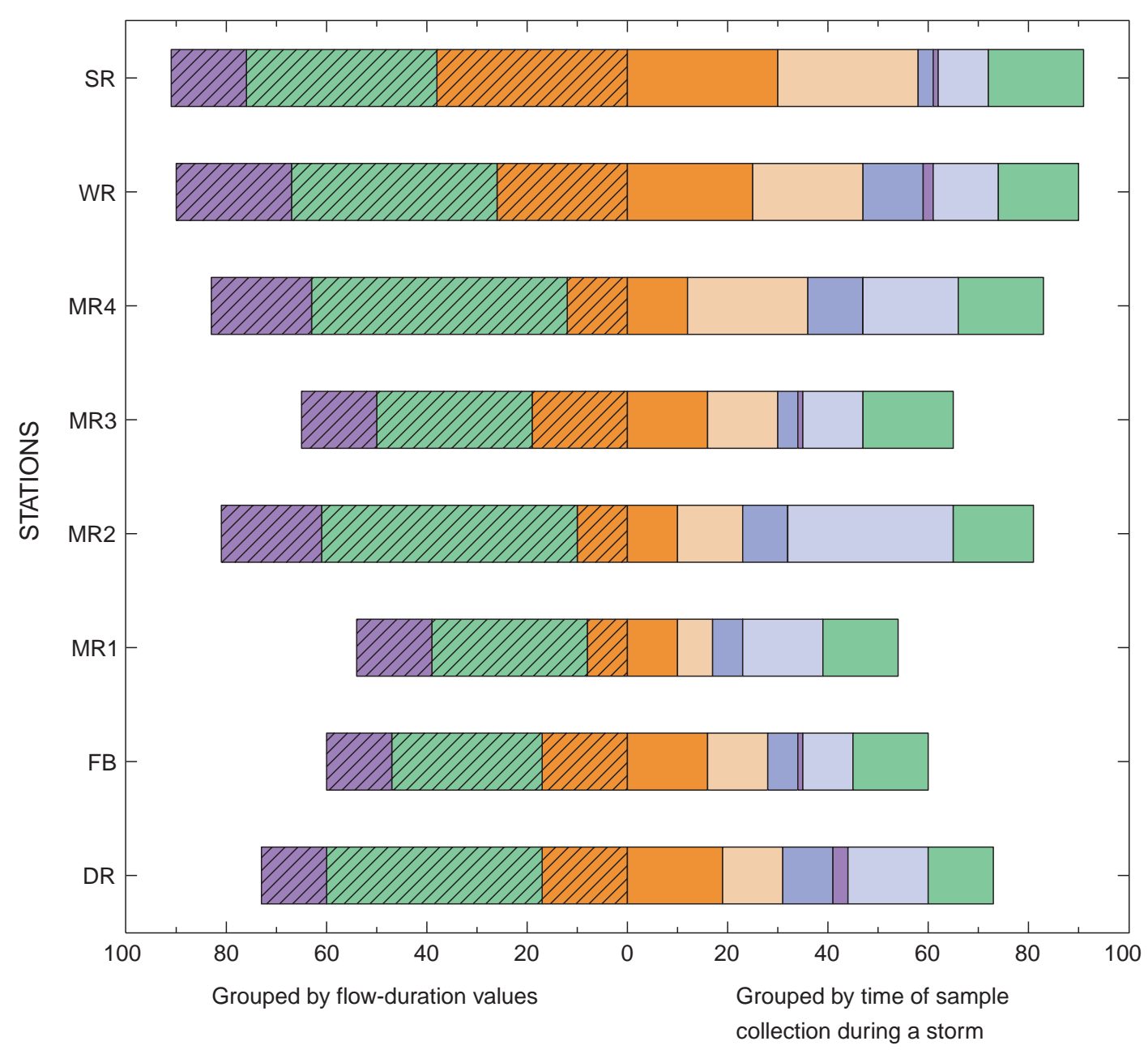

NUMBERS OF SAMPLES COLLECTED

\section{EXPLANATION}

Samples grouped by
flow-duration value

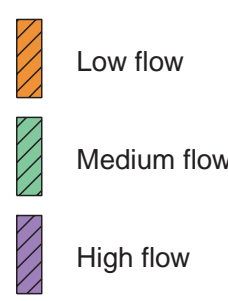

Samples grouped by time of collection during a storm

Base flow $\quad \square$ Rising stormflow $\square$ Falling stormflow
Before a storm $\square$ Peak stormflow $\square$ After a storm

STATIONS

SR, Saddle River at Lodi, N.J.

WR, Whippany River at Morristown, N.J.

MR4, Musconetcong River at Riegelsville, N.J.

MR3, Musconetcong River at Bloomsbury, N.J.

MR2, Musconetcong River at Beattystown, N.J.

MR1, Musconetcong River at Lockwood, N.J.

FB, Flat Brook at Flatbrookville, N.J.

DR, Delaware River at Montague, N.J.

Figure 3. Number of samples collected at stations on the Flat Brook and the Delaware, Musconetcong, Whippany, and Saddle Rivers, N.J., by flow duration and type of flow, water years 1982-97. (Stations are arranged from bottom to top in order of increasing land development in the contributing drainage areas.) 




EXPLANATION
Figure 4. Flow-duration curves for water-quality stations with continuous streamflow records on the Flat Brook and the Delaware, Musconetcong, Whippany, and Saddle Rivers, New Jersey, period of record through 1997.

quality before, during, and after a storm, data for samples collected during rising or peak streamflows were classified as during storm, and data for samples collected during falling streamflows or after a storm were classified as after storm. For a comparison of water quality during low, medium, and high flows, data for samples were grouped as described above.

Yields (area-normalized instantaneous load values) for total phosphorus, nitrogen, nitrate plus nitrite, fecal-coliform bacteria, alkalinity, and chloride were computed by using the equation

$$
\mathrm{Y}=(\mathrm{C} \times \mathrm{Q} \times \mathrm{f}) / \mathrm{A} \text {, }
$$

where

$\mathrm{Y}$ is the yield in pounds per day per square mile $\left((\mathrm{lb} / \mathrm{d}) / \mathrm{mi}^{2}\right)$ or most probable number per day per square mile $\left((\mathrm{MPN} / \mathrm{d}) / \mathrm{mi}^{2}\right)$;
$\mathrm{C}$ is the measured concentration in milligrams per liter $(\mathrm{mg} / \mathrm{L})$ or most probable number per 100 milliliters (MPN/100 mL);

$\mathrm{Q}$ is the instantaneous streamflow in cubic feet per second $\left(\mathrm{ft}^{3} / \mathrm{s}\right)$;

$\mathrm{f}$ is a conversion factor equal to 5.3936 pounds per milligram, seconds per day, liters per cubic feet $\left((\mathrm{lb} / \mathrm{mg})(\mathrm{s} / \mathrm{d})\left(\mathrm{L} / \mathrm{ft}^{3}\right)\right)$ if the concentration is in $\mathrm{mg} / \mathrm{L}$ or $2.45 \times 10^{7}$ seconds per day, milliliters per cubic feet $\left((\mathrm{s} / \mathrm{d})\left(\mathrm{mL} / \mathrm{ft}^{3}\right)\right)$ if the concentration is in MPN/100 mL; and

$\mathrm{A}$ is the drainage area in square miles $\left(\mathrm{mi}^{2}\right)$.

\section{Statistical Methods}

Environmental data, by nature, are nonnormally distributed and, therefore, are more suitably analyzed by nonparametric statistical methods. The data have a lower bound of zero (no negative values are possible); outliers (data values considerably higher or lower than most of the data) regularly occur, causing data frequency plots to be positively skewed; and finally, data are reported only as below or above some threshold (censored data) (Helsel and Hirsch, 1992). Each statistical test was performed on the entire population of values for each streamflow condition. For all statistical computations, censored data values (those values reported as less than the detection limit) were considered equal to their absolute value because of changes in the laboratory reporting levels (detection limits).

For each station, median concentrations of total phosphorus, nitrogen, nitrate plus nitrite, fecalcoliform bacteria, alkalinity, $\mathrm{pH}$, chloride, and specific conductance were determined for samples collected during eight streamflow conditions: (1) during base flow, (2) during stormflow, (3) before a storm, (4) during a storm, (5) after a storm, and during (6) low, (7) medium, and (8) high flows. Median yields for all water-quality constituents except $\mathrm{pH}$ and specific conductance for samples collected during each of these streamflow conditions also were determined. Median concentrations and yields are weighted toward 
Table 2. Estimated flow-duration values for water-quality stations on the Flat Brook and the Delaware, Musconetcong, Whippany, and Saddle Rivers, New Jersey, water years 1982-97

\begin{tabular}{lccc}
\hline & \multicolumn{3}{c}{$\begin{array}{c}\text { Estimated daily streamflow } \\
\text { at indicated flow-duration limit, } \\
\text { in cubic feet per second }\end{array}$} \\
\cline { 2 - 4 } Station name and identifier & \multicolumn{2}{c}{$\begin{array}{c}\text { 75 percent } \\
50 \text { percent }\end{array}$} & 25 percent \\
\hline Delaware River at Montague (DR) & 2,100 & 3,300 & 6,800 \\
Flat Brook at Flatbrookville (FB) & 28 & 83 & 140 \\
Musconetcong River at Lockwood (M1) & 61 & 120 & 120 \\
Musconetcong River at Beattystown (M2) & 130 & 200 & 230 \\
Musconetcong River near Bloomsbury (M3) & 120 & 200 & 330 \\
Musconetcong River at Riegelsville (M4) & 29 & 43 & 67 \\
Whippany River at Morristown (WR) & 44 & 69 & 110 \\
Saddle River a Lodi (SR) & & & \\
\hline
\end{tabular}

values calculated for groups in which a high number of samples was collected. At most stations, more samples were collected during base flow and before storms than during storms; few samples were collected during peak streamflow (fig. 3).

The nonparametric Tukey multiple comparison test was used to detect differences in concentrations and yields among the eight stations during each of the eight streamflow conditions by determining at which station(s) the means of the concentrations or yield ranks differed at the 0.05 significance level (Helsel and Hirsch, 1992). The Tukey test is appropriate for determining differences among groups of unequal size and determining differences among group means. Data are ranked, and significant differences among the groups are indicated by using letters such as A, B, and C. Groups designated as A have similar means, which are higher than those designated as $\mathrm{B}$, which in turn, are higher than those designated as $\mathrm{C}$; stations designated as $\mathrm{AB}$ have means similar to groups designated as $\mathrm{A}$ and $\mathrm{B}$ but are different from those designated as $\mathrm{C}$.
The Kruskal-Wallis nonparametric statistical test was used to determine whether concentrations and yields of each constituent at each station differed at the 0.05 and 0.01 significance levels during three streamflow comparisons--(1) during base flow and stormflow; (2) before, during, and after a storm; and (3) during low, medium, and high flows. This test is used to evaluate whether the populations of the groups being compared are identical by testing the hypothesis that there is no significant difference between group medians; the test is applicable to data sets that are not normally distributed (Helsel and Hirsch, 1992). To conduct the test, the data are ranked from lowest to highest. If no difference is determined among the groups, the average rank for each group (the group median) should be similar to the others and also be close to the overall average rank for all the data. A difference among the groups is indicated when some of the average group ranks are significantly higher or lower than the overall average rank for all the data. 
For stations where the $p$-value of the Kruskal-Wallis test was less than 0.01 , the Tukey test was used to detect differences at the 0.05 significance level between concentrations and yields (1) during base flow and stormflow; (2) before, during, and after a storm; and (3) during low, medium, and high flows. The Kruskal-Wallis test for determining differences at the 0.01 significance level is a more rigorous test than at the 0.05 significance level because statistical results would not be valid at the less significant level (0.05) when the sizes of the groups tested were extremely uneven, as they were for some stations.

\section{COMPARISONS OF WATER QUALITY DURING BASE FLOW AND STORM- FLOW}

Constituents from diffuse, nonpoint sources are transported to the stream in groundwater discharge and by storm runoff. Ground-water discharge to a stream is relatively constant, whereas storm runoff contributes to a stream intermittently. Instream concentrations are the result of constant-rate (point sources and ground-water discharge) and intermittent-rate (storm runoff) contributions that are modified by instream processes.

Nonpoint-source contributions also are affected by the type and intensity of development and historical land use in the contributing drainage areas.

Instream loads of water-quality constituents were affected more by contributions from storm runoff than from point sources and groundwater discharge in streams where yields were higher during runoff conditions (stormflow or a storm) than during non-runoff conditions (base flow or before a storm). In such cases, concentrations might be higher during runoff conditions than during non-runoff conditions. Instream loads of water-quality constituents were affected less by contributions from storm runoff than by contributions from point sources and ground-water discharge in streams where yields during runoff conditions were equal to or lower than yields during non-runoff conditions. In such cases, concentrations would be lower during runoff conditions than during non-runoff conditions. Storm runoff could be an important contributor of selected water-quality constituents to streams even when concentrations during stormflow and storms are lower than during base flow, before a storm, or after a storm because the river could be transporting higher masses (that is, total amounts) of constituents in the high streamflows associated with storm runoff.

In this section, results of statistical tests are discussed by water-quality constituent--nutrients (total phosphorus, nitrogen, and nitrate plus nitrite), fecal-coliform bacteria, alkalinity, $\mathrm{pH}$, chloride, and specific conductance. Two comparisons of water quality (for concentrations and yields) during various streamflow conditions at eight stations are presented. For the first comparison--to determine differences in water quality among the streams--differences in concentrations and yields among the stations (1) during base flow, (2) during stormflow, (3) before a storm, (4) during a storm, and (5) after a storm are discussed. For the second comparison--to evaluate the relative importance of storm runoff at each station--differences in concentrations and yields between (1) base flow and stormflow and (2) before, during, and after a storm at each station are discussed.

\section{$\underline{\text { Nutrients }}$}

The nutrients evaluated as part of this study are total phosphorus, nitrogen, and nitrate plus nitrite. Nitrogen and phosphorus are essential elements for plant and animal growth. Important forms of nitrogen in the aquatic environment are nitrate, nitrite, ammonia, and organic nitrogen. Excess algal growth (eutrophication) or toxicity to aquatic and terrestrial animals can be caused by the combination of high concentrations of nutrients, low streamflow and dissolved oxygen concentration, and high water temperature. For example, total phosphorus concentrations in excess of $0.05 \mathrm{mg} / \mathrm{L}$ in lakes and impoundments and $0.1 \mathrm{mg} / \mathrm{L}$ in streams are detrimental to water quality (New Jersey Department of Environmental Protection, 1998). Nitrogen and phosphorus enter aquatic environments from fertilizers, agricultural wastes, decomposition of organic matter, biotic fixation, and ambient soils and rocks; atmospheric deposition is an important pathway for nitrogen transport within the environment. 
The relative contributions of total nitrogen from storm runoff, and from point sources and ground-water discharge are dependent on the predominant nitrogen species, which can be dissolved or bound to particles. Total nitrogen is a measure of nitrate, nitrite, ammonia, and organic nitrogen. The concentration and yield of total nitrogen in a stream depends on which nitrogen species is predominant. Phosphorus, organic nitrogen, and, to a lesser degree, ammonia are associated with particles that are transported to a stream mainly in storm runoff. Species such as nitrate and nitrite are dissolved and are mainly transported to streams from point sources and in ground-water discharge.

Concentrations and yields of total phosphorus, nitrogen, and nitrate plus nitrite differed among the eight stations during each of the five flow conditions when analyzed by using the Tukey test (table 3). The general pattern of these differences was similar for each streamflow condition-samples from stations on streams draining areas with substantial development, such as those on the Saddle River (SR) and Whippany River (WR), had higher concentrations and yields than samples from stations on streams that drain areas with little development, such as those on the Delaware River (DR) and Flat Brook (FB). Concentrations and yields at station WR generally were lower than those at station SR and higher than those at the stations on the other four streams. The degree of difference in concentrations and yields of total phosphorus, nitrogen, and nitrate plus nitrite at stations along the Musconetcong River (M1, M2, M3, and M4) for each streamflow condition was different for each nutrient.

Concentrations of total phosphorus were low in samples collected during each flow condition at stations FB and DR; median concentrations at stations WR and SR for all flow conditions and at station M1 for base flow exceeded the $0.1 \mathrm{mg} / \mathrm{L}$ NJDEP surface-water standard for phosphorus (New Jersey Department of Environmental Protection, 1998). At all stations for all flow conditions, median concentrations ranged from 0.02 to 0.77 $\mathrm{mg} / \mathrm{L}$, and median yield values ranged from 0.08 to $5.17(\mathrm{lb} / \mathrm{d}) / \mathrm{mi}^{2}$ (tables 4 and 5).
The distributions of total phosphorus concentrations and yields in samples collected before, during, and after a storm are presented in box plots in figures 5 and 6 . Box plots are used to indicate the range of data values and show a center line (median or 50th percentile) splitting a rectangle defined by the 25 th and 75 th percentiles; whiskers are lines drawn from the ends of the box to the 10th and 90th percentiles. (Scatter plots, not box plots, are shown in cases where there are less than nine data values.) In general, concentrations and yields of total phosphorus during each streamflow condition were highest at station SR, lowest at stations FB and DR, and similar among the four stations on the Musconetcong River (M1, M2, M3, and M4); values at station WR generally were less than at station SR and higher than at all other stations (table 3; figs. 5 and 6).

At most stations, concentrations and yields of total phosphorus did not differ (1) between base flow and stormflow or (2) among before, during, and after a storm when analyzed by using the Kruskal-Wallis test (tables 4 and 5). Concentrations at the most upstream station on the Musconetcong River at Lockwood (M1) were higher during base flow than stormflow when analyzed by using the Tukey test (table 4). Yields were higher during stormflow than base flow at stations DR and FB and the station on the Musconetcong River at Beattystown (M2) (table 4) and were higher during a storm than before or after a storm at stations FB and WR (table 5) when analyzed by using the Tukey test.

For station SR, the meaning of the results of the Tukey and Kruskal-Wallis tests to determine differences in concentrations and yields of total phosphorus (and all other water-quality constituents) among various streamflow conditions is uncertain. Much fewer samples were collected during a storm than before or after a storm at this station (figs. 3, 5, and 6). Therefore, the numbers of data values for samples collected at station SR during base flow and during stormflow and before, during, and after a storm are too different for the results of the statistical tests to be meaningful. 
At station FB and the station on the Musconetcong River at Beattystown (M2), yields of total phosphorus were affected more by contributions from storm runoff than by contributions from point sources (where present) and ground-water discharge. Although values were low, yields were significantly higher (1) during stormflow than during base flow and (2) during a storm than before a storm, indicating that the loads carried by the rivers at these stations increased during runoff conditions. At the most upstream and two most downstream stations on the Musconetcong River (M1, M3, and M4) and station SR, yields of total phosphorus were affected less by contributions from storm runoff than by contributions from point sources and ground-water discharge. Yields of total phosphorus at these four stations were similar (1) during base flow and stormflow and (2) before, during, and after a storm, indicating that the loads carried by the river at these stations remained fairly constant during runoff conditions.

Median concentrations of total nitrogen ranged from 0.42 to $6.30 \mathrm{mg} / \mathrm{L}$, and median yields ranged from 1.28 to $55.06(\mathrm{lb} / \mathrm{d}) / \mathrm{mi}^{2}$ in samples collected during each flow condition (tables 4 and 5). Concentrations and yields of total nitrogen in samples collected during base flow and before and after a storm were strongly related to the amount of development in each drainage basin. Values were highest at station SR and lowest at stations FB and DR when analyzed by using the Tukey test (table 3). Concentrations and yields at the upstream station on the Musconetcong River (M4) were lower than those at station SR and higher than those at all other stations during base flow and stormflow, and before and after a storm. Concentrations and yields of total nitrogen in samples collected during stormflow and during a storm at stations SR, WR, M4, and M3, which drain more developed areas, were similar and higher than those at stations DR, FB, $\mathrm{M} 1$, and M2, which drain areas with little development.

Concentrations of total nitrogen at stations SR and WR and the most upstream and downstream stations on the Musconetcong River (M1 and M4, respectively) differed during base flow and stormflow when analyzed by using the Kruskal-Wallis test (table 4); concentrations at these stations were higher during base flow than stormflow when analyzed by using the Tukey test. Concentrations of total nitrogen at most stations were similar before, during, and after a storm when analyzed by using the Kruskal-Wallis test (table 5); concentrations were higher before a storm than during or after a storm at station M1 and higher before a storm than after a storm at station SR when analyzed by using the Tukey test (table 5). Yields of total nitrogen differed (1) during base flow and stormflow at all stations and (2) before, during, and after a storm at most stations when analyzed by using the Kruskal-Wallis test (tables 4 and 5). Yields were higher during stormflow than base flow at all stations (table 4) and were higher during a storm than before or after a storm at stations WR and FB and the two upstream stations on the Musconetcong River (M1 and M2) (table 5) when analyzed by using the Tukey test.

At all stations except DR and SR, yields of total nitrogen were affected more by contributions from storm runoff than by contributions from point sources (where present) and ground-water discharge. Yields at stations FB, M1, M2, M3, M4, and WR were significantly higher (1) during stormflow than base flow and (2) during a storm than before a storm, indicating that the loads carried by these streams increased significantly during runoff conditions. At stations DR and SR, yields of total nitrogen were affected less by contributions from storm runoff than by contributions from point sources and ground-water discharge because yields were higher during stormflow than base flow but similar before, during, and after a storm.

Median concentrations of nitrate plus nitrite ranged from 0.09 to $3.70 \mathrm{mg} / \mathrm{L}$, and median yields ranged from 0.26 to $33.89(\mathrm{lb} / \mathrm{d}) / \mathrm{mi}^{2}$ in samples collected during each flow condition (tables 4 and 5). The distributions of nitrate plus nitrite concentrations and yields in samples collected before, during, and after a storm are presented in box plots in figures 5 and 6 . Concentrations and yields of total nitrogen are strongly related to the amount of development in each drainage basin; values were higher at stations with substantial land development in the areas contributing drainage. The differences in concentrations and yields of nitrate plus nitrite among the stations is similar to that 
Table 3. Results of the Tukey test to determine statistical differences for constituent concentrations and yields among samples collected at water-quality stations on the Flat Brook and the Delaware, Musconetcong, Whippany, and Saddle Rivers, New Jersey, during various streamflow conditions, water years 1982-97

[DR, Delaware River at Montague; FB, Flat Brook at Flatbrookville; M1, Musconetcong River at Lockwood; M2, Musconetcong River at Beattystown; M3, Musconetcong River near Bloomsbury; M4, Musconetcong River at Riegelsville; WR, Whippany River at Morristown; SR, Saddle River at Lodi; differing letters indicate significant differences in rank of mean concentrations and yields among sites at the 0.05 significance level, according to the Tukey test, where $\mathrm{A}$ is the highest and $\mathrm{F}$ is the lowest;-- no value determined]

\begin{tabular}{|c|c|c|c|c|c|c|c|c|c|c|c|c|c|c|c|c|c|}
\hline \multirow{2}{*}{$\begin{array}{c}\text { Water-quality } \\
\text { constituent }\end{array}$} & \multirow{2}{*}{$\begin{array}{l}\text { Streamflow } \\
\text { condition }\end{array}$} & \multicolumn{8}{|c|}{ Rank of difference among mean concentrations } & \multicolumn{8}{|c|}{ Rank of difference among mean yield values } \\
\hline & & DR & FB & M1 & M2 & M3 & M4 & WR & SR & DR & $\mathrm{FB}$ & M1 & M2 & M3 & M4 & WR & SR \\
\hline \multirow[t]{8}{*}{ Total phosphorus } & Base flow & $\mathrm{DE}$ & $\mathrm{E}$ & $\mathrm{BC}$ & $\mathrm{C}$ & $\mathrm{CD}$ & $\mathrm{CD}$ & $\mathrm{B}$ & A & $\mathrm{D}$ & $\mathrm{D}$ & $\mathrm{C}$ & $\mathrm{C}$ & $\mathrm{C}$ & $\mathrm{C}$ & $\mathrm{B}$ & A \\
\hline & Stormflow & $\mathrm{D}$ & $\mathrm{D}$ & $\mathrm{C}$ & $\mathrm{C}$ & $\mathrm{C}$ & $\mathrm{C}$ & B & A & $\mathrm{D}$ & $\mathrm{D}$ & $\mathrm{C}$ & $\mathrm{C}$ & $\mathrm{C}$ & $\mathrm{C}$ & $\mathrm{B}$ & A \\
\hline & Before a storm & $\mathrm{DE}$ & E & $\mathrm{BC}$ & $\mathrm{C}$ & $\mathrm{CD}$ & $\mathrm{CD}$ & B & A & $\mathrm{D}$ & $\mathrm{D}$ & $\mathrm{C}$ & $\mathrm{C}$ & $\mathrm{C}$ & $\mathrm{C}$ & B & A \\
\hline & During a storm & $\mathrm{C}$ & $\mathrm{C}$ & $\mathrm{C}$ & $\mathrm{BC}$ & $\mathrm{C}$ & $\mathrm{BC}$ & $\mathrm{AB}$ & A & $\mathrm{D}$ & $\mathrm{CD}$ & $\mathrm{BCD}$ & $\mathrm{ABC}$ & $\mathrm{CD}$ & $\mathrm{BCD}$ & $\mathrm{AB}$ & A \\
\hline & After a storm & $\mathrm{D}$ & $\mathrm{D}$ & $\mathrm{BC}$ & $\mathrm{BC}$ & $\mathrm{C}$ & $\mathrm{C}$ & B & A & $\mathrm{D}$ & $\mathrm{D}$ & $\mathrm{C}$ & $\mathrm{BC}$ & $\mathrm{C}$ & $\mathrm{C}$ & $\mathrm{B}$ & A \\
\hline & Low flow & $\mathrm{D}$ & $\mathrm{D}$ & $\mathrm{BC}$ & $\mathrm{BC}$ & $\mathrm{CD}$ & $\mathrm{CD}$ & $\mathrm{AB}$ & $\mathrm{A}$ & $\mathrm{BC}$ & $\mathrm{C}$ & $\mathrm{BC}$ & B & B & $\mathrm{BC}$ & $\mathrm{A}$ & A \\
\hline & Medium flow & $\mathrm{DE}$ & E & $\mathrm{C}$ & $\mathrm{C}$ & $\mathrm{CD}$ & $\mathrm{C}$ & $\mathrm{B}$ & $\mathrm{A}$ & $\mathrm{D}$ & D & $\mathrm{C}$ & $\mathrm{C}$ & $\mathrm{C}$ & $\mathrm{C}$ & $\mathrm{B}$ & A \\
\hline & High flow & $\mathrm{C}$ & $\mathrm{C}$ & $\mathrm{C}$ & $\mathrm{BC}$ & $\mathrm{BC}$ & $\mathrm{C}$ & $\mathrm{AB}$ & A & $\mathrm{D}$ & $\mathrm{CD}$ & $\mathrm{CD}$ & $\mathrm{BC}$ & $\mathrm{BC}$ & $\mathrm{CD}$ & $\mathrm{AB}$ & A \\
\hline \multirow[t]{8}{*}{ Total nitrogen } & Base flow & $\mathrm{F}$ & G & $\mathrm{DE}$ & $\mathrm{E}$ & $\mathrm{CD}$ & B & $\mathrm{BC}$ & $\mathrm{A}$ & $\mathrm{F}$ & $\mathrm{F}$ & E & $\mathrm{DE}$ & $\mathrm{CD}$ & $\mathrm{B}$ & $\mathrm{BC}$ & A \\
\hline & Stormflow & $\mathrm{E}$ & E & $\mathrm{D}$ & $\mathrm{D}$ & $\mathrm{C}$ & B & $\mathrm{C}$ & A & E & $\mathrm{E}$ & $\mathrm{D}$ & $\mathrm{CD}$ & $\mathrm{BC}$ & $\mathrm{BC}$ & $\mathrm{B}$ & A \\
\hline & Before a storm & $\mathrm{F}$ & G & $\mathrm{DE}$ & E & $\mathrm{CD}$ & $\mathrm{B}$ & $\mathrm{BC}$ & A & F & $\mathrm{F}$ & E & $\mathrm{DE}$ & $\mathrm{CD}$ & $\mathrm{B}$ & $\mathrm{BC}$ & A \\
\hline & During a storm & $\mathrm{C}$ & $\mathrm{C}$ & $\mathrm{C}$ & $\mathrm{BC}$ & A & A & $\mathrm{AB}$ & A & $\mathrm{D}$ & $\mathrm{BCD}$ & $\mathrm{CD}$ & $\mathrm{ABC}$ & $\mathrm{AB}$ & $\mathrm{ABC}$ & $\mathrm{AB}$ & A \\
\hline & After a storm & $\mathrm{E}$ & E & $\mathrm{D}$ & $\mathrm{D}$ & $\mathrm{C}$ & B & $\mathrm{C}$ & A & $\mathrm{EF}$ & $\mathrm{F}$ & $\mathrm{DE}$ & $\mathrm{CD}$ & $\mathrm{BC}$ & B & $\mathrm{BC}$ & A \\
\hline & Low flow & $\mathrm{E}$ & E & $\mathrm{BC}$ & $\mathrm{D}$ & $\mathrm{C}$ & $\mathrm{B}$ & $\mathrm{BC}$ & A & $\mathrm{DE}$ & E & $\mathrm{CD}$ & $\mathrm{C}$ & $\mathrm{B}$ & $\mathrm{B}$ & $\mathrm{B}$ & A \\
\hline & Medium flow & $\mathrm{E}$ & $\mathrm{F}$ & $\mathrm{D}$ & $\mathrm{D}$ & $\mathrm{C}$ & $\mathrm{B}$ & $\mathrm{C}$ & A & E & $\mathrm{E}$ & $\mathrm{D}$ & $\mathrm{C}$ & $\mathrm{BC}$ & $\mathrm{B}$ & $\mathrm{B}$ & A \\
\hline & High flow & $\mathrm{CD}$ & $\mathrm{D}$ & $\mathrm{C}$ & $\mathrm{C}$ & B & B & B & A & $\mathrm{CD}$ & $\mathrm{D}$ & $\mathrm{C}$ & B & $\mathrm{AB}$ & $\mathrm{AB}$ & $\mathrm{AB}$ & A \\
\hline \multirow[t]{8}{*}{ Nitrate plus nitrite } & Base flow & $\mathrm{D}$ & E & $\mathrm{C}$ & $\mathrm{C}$ & $\mathrm{B}$ & B & B & A & $\mathrm{DE}$ & $\mathrm{E}$ & $\mathrm{D}$ & $\mathrm{C}$ & $\mathrm{B}$ & $\mathrm{B}$ & $\mathrm{B}$ & A \\
\hline & Stormflow & $\mathrm{E}$ & $\mathrm{F}$ & $\mathrm{E}$ & $\mathrm{D}$ & $\mathrm{BC}$ & B & $\mathrm{C}$ & A & $\mathrm{D}$ & $\mathrm{D}$ & $\mathrm{D}$ & $\mathrm{C}$ & $\mathrm{B}$ & B & $\mathrm{B}$ & A \\
\hline & Before a storm & $\mathrm{D}$ & E & $\mathrm{C}$ & $\mathrm{C}$ & B & B & B & A & $\mathrm{DE}$ & E & $\mathrm{D}$ & $\mathrm{C}$ & $\mathrm{B}$ & B & $\mathrm{B}$ & A \\
\hline & During a storm & $\mathrm{DE}$ & $\mathrm{E}$ & $\mathrm{DE}$ & $\mathrm{CD}$ & $\mathrm{ABC}$ & $\mathrm{AB}$ & $\mathrm{BC}$ & A & $\mathrm{E}$ & $\mathrm{CDE}$ & $\mathrm{DE}$ & $\mathrm{BCD}$ & $\mathrm{BC}$ & $\mathrm{ABC}$ & $\mathrm{AB}$ & A \\
\hline & After a storm & $\mathrm{E}$ & $\mathrm{F}$ & $\mathrm{E}$ & $\mathrm{D}$ & $\mathrm{BC}$ & B & $\mathrm{C}$ & A & $\mathrm{D}$ & $\mathrm{E}$ & $\mathrm{D}$ & $\mathrm{C}$ & $\mathrm{B}$ & $\mathrm{AB}$ & $\mathrm{B}$ & A \\
\hline & Low flow & $\mathrm{D}$ & E & $\mathrm{C}$ & $\mathrm{C}$ & $\mathrm{B}$ & $\mathrm{B}$ & $\mathrm{B}$ & $\mathrm{A}$ & DE & $\mathrm{E}$ & $\mathrm{CD}$ & $\mathrm{C}$ & $\mathrm{B}$ & $\mathrm{B}$ & $\mathrm{B}$ & A \\
\hline & Medium flow & $\mathrm{E}$ & $\mathrm{F}$ & E & $\mathrm{D}$ & $\mathrm{BC}$ & $\mathrm{B}$ & $\mathrm{BC}$ & $\mathrm{A}$ & E & $\mathrm{E}$ & $\mathrm{D}$ & $\mathrm{C}$ & $\mathrm{B}$ & $\mathrm{B}$ & $\mathrm{B}$ & A \\
\hline & High flow & $\mathrm{DE}$ & $\mathrm{F}$ & $\mathrm{EF}$ & $\mathrm{D}$ & $\mathrm{BC}$ & B & $\mathrm{C}$ & A & $\mathrm{C}$ & $\mathrm{D}$ & $\mathrm{D}$ & B & A & A & A & A \\
\hline \multirow{8}{*}{$\begin{array}{l}\text { Fecal-coliform } \\
\text { bacteria }\end{array}$} & Base flow & $\mathrm{D}$ & $\mathrm{D}$ & $\mathrm{C}$ & $\mathrm{C}$ & $\mathrm{ABC}$ & $\mathrm{BC}$ & $\mathrm{AB}$ & $\mathrm{A}$ & $\mathrm{D}$ & $\mathrm{D}$ & $\mathrm{C}$ & $\mathrm{C}$ & $\mathrm{BC}$ & $\mathrm{BC}$ & $\mathrm{AB}$ & A \\
\hline & Stormflow & $\mathrm{E}$ & $\mathrm{DE}$ & $\mathrm{CD}$ & $\mathrm{BC}$ & B & B & $\mathrm{A}$ & A & $\mathrm{E}$ & $\mathrm{DE}$ & $\mathrm{CD}$ & $\mathrm{BC}$ & $\mathrm{B}$ & $\mathrm{B}$ & A & A \\
\hline & Before a storm & $\mathrm{D}$ & $\mathrm{D}$ & $\mathrm{C}$ & $\mathrm{C}$ & $\mathrm{ABC}$ & $\mathrm{BC}$ & $\mathrm{AB}$ & $\mathrm{A}$ & $\mathrm{D}$ & $\mathrm{D}$ & $\mathrm{C}$ & $\mathrm{C}$ & $\mathrm{BC}$ & $\mathrm{C}$ & $\mathrm{AB}$ & A \\
\hline & During a storm & $\mathrm{C}$ & $\mathrm{C}$ & $\mathrm{C}$ & $\mathrm{BC}$ & $\mathrm{AB}$ & $\mathrm{A}$ & A & A & $\mathrm{D}$ & $\mathrm{CD}$ & $\mathrm{CD}$ & $\mathrm{BC}$ & $\mathrm{AB}$ & $\mathrm{AB}$ & A & A \\
\hline & After a storm & $\mathrm{D}$ & $\mathrm{CD}$ & $\mathrm{BC}$ & B & B & B & A & A & $\mathrm{D}$ & $\mathrm{D}$ & $\mathrm{C}$ & $\mathrm{BC}$ & $\mathrm{B}$ & $\mathrm{BC}$ & A & A \\
\hline & Low flow & $\mathrm{C}$ & $\mathrm{C}$ & B & $\mathrm{B}$ & $\mathrm{AB}$ & $\mathrm{AB}$ & $\mathrm{AB}$ & A & $\mathrm{D}$ & $\mathrm{D}$ & $\mathrm{C}$ & $\mathrm{BC}$ & $\mathrm{BC}$ & $\mathrm{BC}$ & $\mathrm{AB}$ & A \\
\hline & Medium flow & $\mathrm{C}$ & $\mathrm{C}$ & B & B & A & A & A & A & $\mathrm{C}$ & $\mathrm{C}$ & B & B & A & A & A & A \\
\hline & High flow & E & $\mathrm{DE}$ & $\mathrm{CDE}$ & $\mathrm{CD}$ & $\mathrm{BC}$ & $\mathrm{BC}$ & A & $\mathrm{AB}$ & E & $\mathrm{DE}$ & $\mathrm{CDE}$ & $\mathrm{CD}$ & $\mathrm{BC}$ & $\mathrm{BC}$ & A & $\mathrm{AB}$ \\
\hline
\end{tabular}


Table 3. Results of the Tukey test to determine statistical differences for constituent concentrations and yields among samples collected at water-quality stations on the Flat Brook and the Delaware, Musconetcong, Whippany, and Saddle Rivers, New Jersey, during various streamflow conditions, water years 1982-97--Continued

\begin{tabular}{|c|c|c|c|c|c|c|c|c|c|c|c|c|c|c|c|c|c|}
\hline \multirow{2}{*}{$\begin{array}{c}\text { Water-quality } \\
\text { constituent }\end{array}$} & \multirow{2}{*}{$\begin{array}{l}\text { Streamflow } \\
\text { condition }\end{array}$} & \multicolumn{8}{|c|}{ Rank in difference among mean concentrations } & \multicolumn{8}{|c|}{ Rank in difference among mean yield values } \\
\hline & & DR & FB & M1 & M2 & M3 & M4 & WR & $\mathrm{SR}$ & DR & FB & M1 & M2 & M3 & M4 & WR & SR \\
\hline \multirow[t]{8}{*}{ Alkalinity } & Base flow & $\mathrm{E}$ & $\mathrm{C}$ & $\mathrm{D}$ & $\mathrm{BC}$ & $\mathrm{AB}$ & $\mathrm{AB}$ & $\mathrm{D}$ & A & $\mathrm{D}$ & $\mathrm{CD}$ & $\mathrm{CD}$ & $\mathrm{AB}$ & $\mathrm{AB}$ & A & $\mathrm{BC}$ & A \\
\hline & Stormflow & $\mathrm{D}$ & $\mathrm{C}$ & $\mathrm{C}$ & $\mathrm{B}$ & $\mathrm{AB}$ & A & $\mathrm{C}$ & A & $\mathrm{D}$ & $\mathrm{C}$ & $\mathrm{C}$ & $\mathrm{AB}$ & A & A & $\mathrm{BC}$ & A \\
\hline & Before a storm & $\mathrm{E}$ & $\mathrm{C}$ & $\mathrm{D}$ & $\mathrm{BC}$ & $\mathrm{AB}$ & $\mathrm{AB}$ & $\mathrm{D}$ & A & $\mathrm{D}$ & $\mathrm{CD}$ & $\mathrm{CD}$ & $\mathrm{AB}$ & $\mathrm{AB}$ & $\mathrm{A}$ & $\mathrm{BC}$ & A \\
\hline & During a storm & $\mathrm{C}$ & $\mathrm{BC}$ & $\mathrm{BC}$ & $\mathrm{AB}$ & A & A & $\mathrm{BC}$ & A & $\mathrm{C}$ & $\mathrm{AB}$ & $\mathrm{B}$ & $\mathrm{AB}$ & $\mathrm{AB}$ & $\mathrm{AB}$ & $\mathrm{AB}$ & A \\
\hline & After a storm & $\mathrm{D}$ & $\mathrm{C}$ & $\mathrm{C}$ & B & $\mathrm{ABC}$ & $\mathrm{AB}$ & $\mathrm{C}$ & A & $\mathrm{D}$ & $\mathrm{C}$ & $\mathrm{BC}$ & $\mathrm{AB}$ & $\mathrm{A}$ & A & $\mathrm{C}$ & A \\
\hline & Low flow & $\mathrm{C}$ & $\mathrm{B}$ & $\mathrm{B}$ & A & $\mathrm{A}$ & $\mathrm{A}$ & $\mathrm{B}$ & A & $\mathrm{D}$ & $\mathrm{D}$ & $\mathrm{D}$ & $\mathrm{BC}$ & $\mathrm{AB}$ & $\mathrm{AB}$ & $\mathrm{CD}$ & A \\
\hline & Medium flow & $\mathrm{E}$ & $\mathrm{D}$ & $\mathrm{D}$ & $\mathrm{C}$ & $\mathrm{BC}$ & $\mathrm{B}$ & $\mathrm{D}$ & A & $\mathrm{D}$ & $\mathrm{C}$ & $\mathrm{C}$ & $\mathrm{B}$ & $\mathrm{AB}$ & $\mathrm{B}$ & $\mathrm{C}$ & A \\
\hline & High flow & $\mathrm{D}$ & $\mathrm{D}$ & $\mathrm{D}$ & $\mathrm{C}$ & $\mathrm{BC}$ & $\mathrm{B}$ & $\mathrm{D}$ & A & $\mathrm{D}$ & $\mathrm{BC}$ & $\mathrm{C}$ & $\mathrm{AB}$ & A & $\mathrm{AB}$ & $\mathrm{BC}$ & A \\
\hline \multirow[t]{8}{*}{$\mathrm{pH}$} & Base flow & B & A & $\mathrm{B}$ & A & $\mathrm{A}$ & A & A & B & -- & -- & -- & -- & -- & -- & -- & -- \\
\hline & Stormflow & $\mathrm{B}$ & $\mathrm{B}$ & $\mathrm{B}$ & A & A & $\mathrm{A}$ & $\mathrm{B}$ & B & -- & -- & -- & -- & -- & -- & -- & -- \\
\hline & Before a storm & $\mathrm{B}$ & $\mathrm{A}$ & $\mathrm{B}$ & A & $\mathrm{A}$ & $\mathrm{A}$ & $\mathrm{A}$ & B & -- & -- & -- & -- & -- & -- & -- & -- \\
\hline & During a storm & B & $\mathrm{AB}$ & $\mathrm{AB}$ & A & $\mathrm{AB}$ & $\mathrm{AB}$ & $\mathrm{B}$ & B & -- & -- & -- & -- & -- & -- & -- & -- \\
\hline & After a storm & $\mathrm{B}$ & $\mathrm{B}$ & $\mathrm{B}$ & A & A & $\mathrm{A}$ & $\mathrm{B}$ & B & -- & -- & -- & -- & -- & -- & -- & -- \\
\hline & Low flow & $\mathrm{B}$ & $\mathrm{A}$ & $\mathrm{B}$ & A & $\mathrm{A}$ & A & $\mathrm{A}$ & B & -- & -- & -- & -- & -- & -- & -- & -- \\
\hline & Medium flow & $\mathrm{C}$ & $\mathrm{BC}$ & $\mathrm{C}$ & A & A & A & $\mathrm{AB}$ & $\mathrm{BC}$ & -- & -- & -- & -- & -- & -- & -- & -- \\
\hline & High flow & $\mathrm{C}$ & $\mathrm{BC}$ & $\mathrm{ABC}$ & A & $\mathrm{ABC}$ & $\mathrm{AB}$ & $\mathrm{AB}$ & $\mathrm{BC}$ & -- & -- & -- & -- & -- & -- & -- & -- \\
\hline \multirow[t]{8}{*}{ Chloride } & Base flow & $\mathrm{D}$ & $\mathrm{D}$ & $\mathrm{B}$ & B & $\mathrm{C}$ & $\mathrm{C}$ & $\mathrm{B}$ & A & $\mathrm{DE}$ & $\mathrm{E}$ & $\mathrm{BC}$ & $\mathrm{BC}$ & $\mathrm{CD}$ & $\mathrm{C}$ & $\mathrm{AB}$ & A \\
\hline & Stormflow & $\mathrm{D}$ & $\mathrm{D}$ & $\mathrm{B}$ & B & $\mathrm{BC}$ & $\mathrm{C}$ & $\mathrm{B}$ & A & $\mathrm{D}$ & $\mathrm{D}$ & $\mathrm{BC}$ & $\mathrm{ABC}$ & $\mathrm{AB}$ & $\mathrm{C}$ & $\mathrm{AB}$ & A \\
\hline & Before a storm & $\mathrm{D}$ & $\mathrm{D}$ & $\mathrm{B}$ & B & $\mathrm{C}$ & $\mathrm{C}$ & $\mathrm{B}$ & A & $\mathrm{DE}$ & $\mathrm{E}$ & $\mathrm{BC}$ & $\mathrm{BC}$ & $\mathrm{CD}$ & $\mathrm{C}$ & $\mathrm{AB}$ & A \\
\hline & During a storm & $\mathrm{D}$ & $\mathrm{CD}$ & $\mathrm{B}$ & B & $\mathrm{BCD}$ & $\mathrm{BCD}$ & $\mathrm{BC}$ & A & $\mathrm{C}$ & $\mathrm{BC}$ & $\mathrm{AB}$ & $\mathrm{AB}$ & $\mathrm{AB}$ & $\mathrm{BC}$ & A & A \\
\hline & After a storm & $\mathrm{E}$ & $\mathrm{E}$ & $\mathrm{BC}$ & $\mathrm{BC}$ & $\mathrm{CD}$ & $\mathrm{D}$ & $\mathrm{B}$ & A & $\mathrm{C}$ & $\mathrm{C}$ & $\mathrm{AB}$ & $\mathrm{AB}$ & $\mathrm{AB}$ & $\mathrm{B}$ & $\mathrm{AB}$ & A \\
\hline & Low flow & $\mathrm{E}$ & $\mathrm{DE}$ & A & $\mathrm{B}$ & $\mathrm{C}$ & $\mathrm{CD}$ & $\mathrm{B}$ & A & $\mathrm{D}$ & $\mathrm{D}$ & $\mathrm{BC}$ & $\mathrm{BC}$ & $\mathrm{C}$ & $\mathrm{CD}$ & $\mathrm{B}$ & A \\
\hline & Medium flow & $\mathrm{F}$ & $\mathrm{F}$ & $\mathrm{BC}$ & $\mathrm{CD}$ & $\mathrm{DE}$ & $\mathrm{E}$ & $\mathrm{B}$ & A & E & $\mathrm{E}$ & $\mathrm{CD}$ & $\mathrm{BC}$ & $\mathrm{CD}$ & $\mathrm{D}$ & $\mathrm{B}$ & A \\
\hline & High flow & $\mathrm{C}$ & $\mathrm{C}$ & $\mathrm{B}$ & $\mathrm{B}$ & B & $\mathrm{B}$ & $\mathrm{B}$ & A & $\mathrm{D}$ & $\mathrm{C}$ & $\mathrm{AB}$ & $\mathrm{A}$ & $\mathrm{A}$ & $\mathrm{B}$ & A & A \\
\hline \multirow{8}{*}{$\begin{array}{l}\text { Specific } \\
\text { conductance }\end{array}$} & Base flow & $\mathrm{E}$ & $\mathrm{D}$ & $\mathrm{BC}$ & B & $\mathrm{BC}$ & $\mathrm{BC}$ & $\mathrm{C}$ & A & -- & -- & -- & -- & -- & -- & -- & -- \\
\hline & Stormflow & $\mathrm{D}$ & $\mathrm{C}$ & $\mathrm{B}$ & B & $\mathrm{B}$ & $\mathrm{B}$ & $\mathrm{B}$ & A & -- & -- & -- & -- & -- & -- & -- & -- \\
\hline & Before a storm & $\mathrm{D}$ & $\mathrm{E}$ & $\mathrm{BC}$ & B & $\mathrm{BC}$ & $\mathrm{BC}$ & $\mathrm{C}$ & A & -- & -- & -- & -- & -- & -- & -- & -- \\
\hline & During a storm & $\mathrm{D}$ & $\mathrm{CD}$ & $\mathrm{BCD}$ & B & $\mathrm{B}$ & $\mathrm{B}$ & $\mathrm{BC}$ & A & -- & -- & -- & -- & -- & -- & -- & -- \\
\hline & After a storm & $\mathrm{D}$ & $\mathrm{C}$ & $\mathrm{B}$ & B & $\mathrm{B}$ & B & $\mathrm{B}$ & A & -- & -- & -- & -- & -- & -- & -- & -- \\
\hline & Low flow & $\mathrm{E}$ & $\mathrm{D}$ & $\mathrm{B}$ & B & $\mathrm{BC}$ & $\mathrm{B}$ & $\mathrm{C}$ & A & -- & -- & -- & -- & -- & -- & -- & -- \\
\hline & Medium flow & $\mathrm{D}$ & $\mathrm{C}$ & $\mathrm{B}$ & B & B & $\mathrm{B}$ & $\mathrm{B}$ & A & -- & -- & -- & -- & -- & -- & -- & -- \\
\hline & High flow & $\mathrm{C}$ & $\mathrm{C}$ & $\mathrm{B}$ & B & B & $\mathrm{B}$ & $\mathrm{B}$ & A & -- & -- & -- & -- & -- & -- & -- & -- \\
\hline
\end{tabular}


Table 4. Median concentrations and yields of selected constituents and results of the Tukey and Kruskal-Wallis tests to determine statistical differences between samples collected during base flow and stormflow at each water-quality station on the Flat Brook and the Delaware, Musconetcong, Whippany, and Saddle Rivers, New Jersey, water years 1982-97

[DR, Delaware River at Montague; FB, Flat Brook at Flatbrookville; M1, Musconetcong River at Lockwood; M2, Musconetcong River at Beattystown; M3, Musconetcong River near Bloomsbury; M4, Musconetcong River at Riegelsville; WR, Whippany River at Morristown; SR, Saddle River at Lodi; differing letters indicate significant differences in median concentrations or yields at the 0.05 significance level, according to the Tukey test, where A is larger and B is smaller; all concentrations are in milligrams per liter, except for specific conductance which is in microsiemens per centimeter at 25 degrees Celsius and bacteria which are in most probable number per 100 milliliters; yields are in pounds per day per square mile, except for bacteria which are in most probable number per day per square mile; bold type indicates $\mathrm{p}$ value is less than 0.05 , according to the Kruskal-Wallis test; shading indicates $p$ value is less than 0.01 , according to the KruskalWallis test; --, no value determined]

\begin{tabular}{|c|c|c|c|c|c|c|c|}
\hline \multirow[b]{3}{*}{ Water-quality constituent } & \multirow{3}{*}{$\begin{array}{l}\text { Water- } \\
\text { quality } \\
\text { station }\end{array}$} & \multicolumn{4}{|c|}{ Tukey test } & \multirow{2}{*}{\multicolumn{2}{|c|}{ Kruskal-Wallis test, p-value }} \\
\hline & & \multicolumn{2}{|c|}{ Median concentration } & \multicolumn{2}{|c|}{ Median yield } & & \\
\hline & & Base flow & Stormflow & Base flow & Stormflow & Concentration & Yield \\
\hline \multirow[t]{8}{*}{ Total phosphorus } & DR & 0.03 & 0.03 & $0.11 \mathrm{~B}$ & $0.18 \mathrm{~A}$ & 0.9882 & 0.0074 \\
\hline & FB & .02 & .02 & $.08 \mathrm{~B}$ & $.24 \mathrm{~A}$ & .7360 & .0005 \\
\hline & M1 & $.10 \mathrm{~A}$ & $.06 \mathrm{~B}$ & .36 & .57 & .0084 & .0405 \\
\hline & M2 & .08 & .07 & $.23 \mathrm{~B}$ & $.92 \mathrm{~A}$ & .5890 & .0037 \\
\hline & M3 & .07 & .06 & .28 & .55 & .6687 & .0153 \\
\hline & M4 & .06 & .06 & .35 & .50 & .7934 & .0396 \\
\hline & WR & .24 & .18 & 1.29 & 1.95 & .1121 & .0168 \\
\hline & SR & .77 & .42 & 4.00 & 4.67 & ${ }^{1} .0017$ & .0153 \\
\hline \multirow[t]{8}{*}{ Total nitrogen } & DR & .71 & .67 & $2.43 \mathrm{~B}$ & $3.93 \mathrm{~A}$ & .4570 & .0066 \\
\hline & $\mathrm{FB}$ & .42 & .46 & $1.28 \mathrm{~B}$ & $5.20 \mathrm{~A}$ & .2380 & .0004 \\
\hline & M1 & $2.03 \mathrm{~A}$ & $1.09 \mathrm{~B}$ & $5.54 \mathrm{~B}$ & $10.45 \mathrm{~A}$ & .0002 & .0001 \\
\hline & M2 & 1.78 & 1.45 & $6.86 \mathrm{~B}$ & $14.06 \mathrm{~A}$ & .0124 & .0001 \\
\hline & M3 & 2.16 & 1.99 & $9.22 \mathrm{~B}$ & $18.96 \mathrm{~A}$ & .0881 & .0001 \\
\hline & M4 & $2.78 \mathrm{~A}$ & $2.46 \mathrm{~B}$ & $13.74 \mathrm{~B}$ & $20.96 \mathrm{~A}$ & .0048 & .0004 \\
\hline & WR & $2.30 \mathrm{~A}$ & $2.00 \mathrm{~B}$ & $13.24 \mathrm{~B}$ & $24.77 \mathrm{~A}$ & .0049 & .0001 \\
\hline & SR & $6.30 \mathrm{~A}$ & $3.85 \mathrm{~B}$ & $31.33 \mathrm{~B}$ & $42.00 \mathrm{~A}$ & .0001 & .0009 \\
\hline \multirow[t]{8}{*}{ Nitrate plus nitrite } & DR & .37 & .36 & 1.20 & 2.05 & .5275 & .0299 \\
\hline & FB & .09 & .16 & $.26 \mathrm{~B}$ & $1.20 \mathrm{~A}$ & .0396 & .0007 \\
\hline & M1 & $.55 \mathrm{~A}$ & $.34 \mathrm{~B}$ & 2.60 & 3.41 & .0004 & .0494 \\
\hline & M2 & $1.10 \mathrm{~A}$ & $.72 \mathrm{~B}$ & $4.50 \mathrm{~B}$ & $7.74 \mathrm{~A}$ & .0012 & .0002 \\
\hline & M3 & $1.89 \mathrm{~A}$ & $1.46 \mathrm{~B}$ & $7.76 \mathrm{~B}$ & $15.90 \mathrm{~A}$ & .0037 & .0003 \\
\hline & M4 & 1.86 & 1.65 & $8.71 \mathrm{~B}$ & $15.28 \mathrm{~A}$ & .0192 & .0005 \\
\hline & WR & $1.64 \mathrm{~A}$ & $1.34 \mathrm{~B}$ & $8.20 \mathrm{~B}$ & $15.88 \mathrm{~A}$ & .0001 & .0001 \\
\hline & $\mathrm{SR}$ & 3.70 & 2.66 & $18.00 \mathrm{~B}$ & $30.51 \mathrm{~A}$ & .0125 & .0001 \\
\hline \multirow[t]{10}{*}{ Fecal-coliform bacteria } & DR & 20 & 20 & $3.70 \times 10^{8} \mathrm{~B}$ & $7.00 \times 10^{8} \mathrm{~A}$ & .2766 & .0003 \\
\hline & FB & 20 & 20 & $4.80 \times 10^{8} \mathrm{~B}$ & $1.20 \times 10^{9} \mathrm{~A}$ & .2478 & .0002 \\
\hline & M1 & 330 & 110 & $4.30 \times 10^{9}$ & $3.20 \times 10^{9}$ & .1664 & .4410 \\
\hline & M2 & 170 & 130 & $2.90 \times 10^{9}$ & $5.10 \times 10^{9}$ & .8235 & .0777 \\
\hline & M3 & 475 & 490 & $8.60 \times 10^{9}$ & $2.20 \times 10^{10}$ & .9107 & .0192 \\
\hline & M4 & 320 & 490 & $7.60 \times 10^{9}$ & $1.30 \times 10^{10}$ & .6892 & .0573 \\
\hline & & & & & $8.60 \times 10^{10}$ & & \\
\hline & WR & 790 & 2,050 & $2.20 \times 10^{10} \mathrm{~B}$ & A & .0260 & .0003 \\
\hline & & & & & $9.60 \times 10^{10}$ & & \\
\hline & SR & 1,700 & 2,850 & $4.00 \times 10^{10} \mathrm{~B}$ & A & .2333 & .0041 \\
\hline \multirow[t]{7}{*}{ Alkalinity } & DR & 15 & 13 & 57 & 80 & .1287 & .0262 \\
\hline & FB & $87 \mathrm{~A}$ & $54 \mathrm{~B}$ & $121 \mathrm{~B}$ & $486 \mathrm{~A}$ & .0074 & .0041 \\
\hline & M1 & $65 \mathrm{~A}$ & $53 \mathrm{~B}$ & $194 \mathrm{~B}$ & $452 \mathrm{~A}$ & .0002 & .0001 \\
\hline & M2 & $104 \mathrm{~A}$ & $74 \mathrm{~B}$ & $429 \mathrm{~B}$ & $778 \mathrm{~A}$ & .0001 & .0001 \\
\hline & M3 & $124 \mathrm{~A}$ & $80 \mathrm{~B}$ & $430 \mathrm{~B}$ & $920 \mathrm{~A}$ & .0001 & .0001 \\
\hline & M4 & $114 \mathrm{~A}$ & $89 \mathrm{~B}$ & $549 \mathrm{~B}$ & $808 \mathrm{~A}$ & .0001 & .0001 \\
\hline & WR & $62 \mathrm{~A}$ & $46 \mathrm{~B}$ & $327 \mathrm{~B}$ & $488 \mathrm{~A}$ & .0001 & .0001 \\
\hline
\end{tabular}


Table 4. Median concentrations and yields of selected constituents and results of the Tukey and Kruskal-Wallis tests to determine statistical differences between samples collected during base flow and stormflow at each water-quality station on the Flat Brook and the Delaware, Musconetcong, Whippany, and Saddle Rivers, New Jersey, water years 1982-97--Continued

\begin{tabular}{|c|c|c|c|c|c|c|c|}
\hline & \multirow[b]{2}{*}{ SR } & & & \multirow[b]{2}{*}{$653 \mathrm{~B}$} & \multirow[b]{2}{*}{$1,094 \mathrm{~A}$} & & \multirow[b]{2}{*}{.0001} \\
\hline & & $124 \mathrm{~A}$ & $102 \mathrm{~B}$ & & & .0001 & \\
\hline \multirow[b]{3}{*}{ Water-quality constituent } & \multirow{3}{*}{$\begin{array}{l}\text { Water- } \\
\text { quality } \\
\text { station }\end{array}$} & \multicolumn{4}{|c|}{ Tukey test } & & \\
\hline & & \multicolumn{2}{|c|}{ Median concentration } & \multicolumn{2}{|c|}{ Median yield } & \multicolumn{2}{|c|}{ Kruskal-Wallis test, p-value } \\
\hline & & Base flow & Stormflow & Base flow & Stormflow & Concentration & Yield \\
\hline \multirow[t]{8}{*}{$\mathrm{pH}$} & DR & 7.7 & 7.6 & -- & -- & .2834 & -- \\
\hline & FB & 8.0 & 7.8 & -- & -- & .0151 & -- \\
\hline & M1 & 7.8 & 7.8 & -- & -- & .6866 & -- \\
\hline & M2 & 8.2 & 8.1 & -- & -- & .4137 & -- \\
\hline & M3 & 8.2 & 8.2 & -- & -- & .5950 & -- \\
\hline & M4 & 8.1 & 8.2 & -- & -- & .7068 & -- \\
\hline & WR & $8.0 \mathrm{~A}$ & $7.8 \mathrm{~B}$ & -- & -- & .0001 & -- \\
\hline & SR & 7.7 & 7.7 & -- & -- & .9866 & -- \\
\hline \multirow[t]{8}{*}{ Chloride } & DR & 8.8 & 8.6 & 29 & 54 & .6947 & .0122 \\
\hline & $\mathrm{FB}$ & 15 & 12 & $27 \mathrm{~B}$ & $124 \mathrm{~A}$ & .0944 & .0001 \\
\hline & M1 & $48 \mathrm{~A}$ & $42 \mathrm{~B}$ & $154 \mathrm{~B}$ & $331 \mathrm{~A}$ & .0096 & .0001 \\
\hline & M2 & $47 \mathrm{~A}$ & $38 \mathrm{~B}$ & $183 \mathrm{~B}$ & $360 \mathrm{~A}$ & .0033 & .0001 \\
\hline & M3 & 30 & 35 & $103 \mathrm{~B}$ & $430 \mathrm{~A}$ & .0395 & .0001 \\
\hline & M4 & 28 & 26 & $126 \mathrm{~B}$ & $277 \mathrm{~A}$ & .6059 & .0002 \\
\hline & WR & 46 & 42 & $260 \mathrm{~B}$ & $500 \mathrm{~A}$ & .0788 & .0001 \\
\hline & SR & $82 \mathrm{~A}$ & $70 \mathrm{~B}$ & $401 \mathrm{~B}$ & $707 \mathrm{~A}$ & .0082 & .0008 \\
\hline \multirow[t]{8}{*}{ Specific conductance } & DR & $87 \mathrm{~A}$ & $82 \mathrm{~B}$ & -- & -- & .0017 & -- \\
\hline & FB & $196 \mathrm{~A}$ & $170 \mathrm{~B}$ & -- & -- & .0018 & -- \\
\hline & M1 & $360 \mathrm{~A}$ & $290 \mathrm{~B}$ & -- & -- & .0008 & -- \\
\hline & M2 & $414 \mathrm{~A}$ & $318 \mathrm{~B}$ & -- & -- & .0001 & -- \\
\hline & M3 & $362 \mathrm{~A}$ & $324 \mathrm{~B}$ & -- & -- & .0007 & -- \\
\hline & M4 & $372 \mathrm{~A}$ & 323 B & -- & -- & .0001 & -- \\
\hline & WR & $348 \mathrm{~A}$ & $298 \mathrm{~B}$ & -- & -- & .0001 & -- \\
\hline & SR & $636 \mathrm{~A}$ & $528 \mathrm{~B}$ & -- & -- & .0001 & -- \\
\hline
\end{tabular}

${ }^{1}$ Unequal group size. Too few observations in one or more groups for meaningful statistical results. 
Table 5. Median concentrations and yields of selected constituents and results of the Tukey and Kruskal-Wallis tests to determine statistical differences among samples collected before, during, and after a storm at each water-quality station on the Flat Brook and the Delaware, Musconetcong, Whippany, and Saddle Rivers, New Jersey, water years 1982-97

[DR, Delaware River at Montague; FB, Flat Brook at Flatbrookville; M1, Musconetcong River at Lockwood; M2, Musconetcong River at Beattystown; M3, Musconetcong River near Bloomsbury; M4, Musconetcong River at Riegelsville; WR, Whippany River at Morristown; SR, Saddle River at Lodi; differing letters indicate significant differences in median concentrations or yields at the 0.05 significance level, according to the Tukey test, where A is larger and B is smaller; all concentrations are in milligrams per liter, except for specific conductance which is in microsiemens per centimeter at 25 degrees Celsius and bacteria which are in most probable number per 100 milliliters; yields are in pounds per day per square mile, except for bacteria which are in most probable number per day per square mile; bold type indicates $\mathrm{p}$ values is less than 0.05 , according to the KruskalWallis tesshadingng indicates $\mathrm{p}$ value is less than 0.01 , according to the Kruskal-Wallis test; --, no value determined]

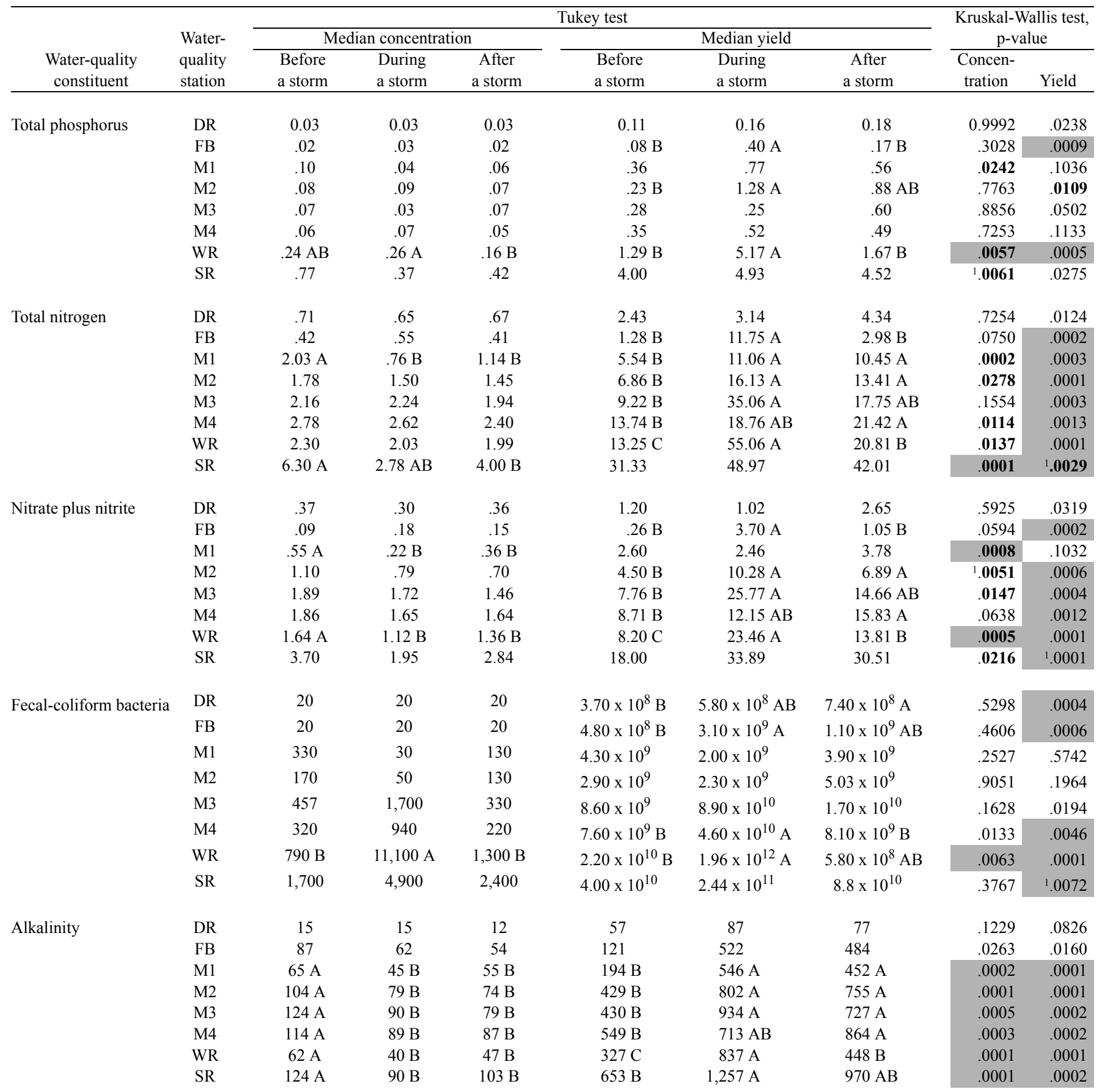


Table 5. Median concentrations and yields of selected constituents and results of the Tukey and Kruskal-Wallis tests to determine statistical differences among samples collected before, during, and after a storm at each water-quality station on the Flat Brook and the Delaware, Musconetcong, Whippany, and Saddle Rivers, New Jersey, water years 1982-97--Continued

\begin{tabular}{|c|c|c|c|c|c|c|c|c|c|}
\hline \multirow[b]{3}{*}{$\begin{array}{c}\text { Water-quality } \\
\text { constituent }\end{array}$} & \multirow{3}{*}{$\begin{array}{l}\text { Water- } \\
\text { quality } \\
\text { station }\end{array}$} & \multicolumn{6}{|c|}{ Tukey test } & \multirow{2}{*}{\multicolumn{2}{|c|}{$\begin{array}{c}\text { Kruskal-Wallis test, } \\
\text { p-value }\end{array}$}} \\
\hline & & \multicolumn{3}{|c|}{ Median concentration } & \multicolumn{3}{|c|}{ Median yield } & & \\
\hline & & $\begin{array}{l}\text { Before } \\
\text { a storm }\end{array}$ & $\begin{array}{l}\text { During } \\
\text { a storm }\end{array}$ & $\begin{array}{c}\text { After } \\
\text { a storm }\end{array}$ & $\begin{array}{l}\text { Before } \\
\text { a storm }\end{array}$ & $\begin{array}{l}\text { During } \\
\text { a storm }\end{array}$ & $\begin{array}{c}\text { After } \\
\text { a storm }\end{array}$ & $\begin{array}{c}\text { Concen- } \\
\text { tration }\end{array}$ & Yield \\
\hline \multirow[t]{8}{*}{$\mathrm{pH}$} & DR & 7.7 & 7.5 & 7.6 & -- & -- & -- & .5571 & -- \\
\hline & FB & 8.0 & 7.7 & 7.8 & -- & -- & -- & .0454 & -- \\
\hline & M1 & 7.8 & 8.0 & 7.7 & -- & -- & -- & .4723 & -- \\
\hline & M2 & 8.2 & 8.2 & 8.1 & -- & -- & -- & .5958 & -- \\
\hline & M3 & 8.2 & 8.0 & 8.2 & -- & -- & -- & .5610 & -- \\
\hline & M4 & 8.1 & 7.8 & 8.2 & -- & -- & -- & .0349 & -- \\
\hline & WR & $8.0 \mathrm{~A}$ & $7.6 \mathrm{C}$ & $7.8 \mathrm{~B}$ & -- & -- & -- & .0001 & -- \\
\hline & SR & 7.7 & 7.6 & 7.7 & -- & -- & -- & .7647 & -- \\
\hline \multirow[t]{8}{*}{ Chloride } & DR & 8.8 & 9.4 & 8.4 & 29 & 57 & 50 & .6304 & .0416 \\
\hline & FB & 15 & 12 & 12 & $27 \mathrm{~B}$ & $165 \mathrm{~A}$ & $120 \mathrm{AB}$ & .2438 & .0005 \\
\hline & M1 & 48 & 33 & 42 & $154 \mathrm{~B}$ & $418 \mathrm{~A}$ & $331 \mathrm{~A}$ & .0271 & .0002 \\
\hline & M2 & 47 & 35 & 38 & $183 \mathrm{~B}$ & $408 \mathrm{~A}$ & $351 \mathrm{~A}$ & .0132 & .0001 \\
\hline & M3 & 30 & 35 & 35 & 103.B & $430 \mathrm{~A}$ & $443 \mathrm{~A}$ & .1170 & .0001 \\
\hline & M4 & 28 & 24 & 29 & $126 \mathrm{~B}$ & $250 \mathrm{AB}$ & $304 \mathrm{~A}$ & .3240 & .0003 \\
\hline & WR & 46 & 30 & 42 & $260 \mathrm{~B}$ & $624 \mathrm{~A}$ & $454 \mathrm{~A}$ & .0742 & .0001 \\
\hline & SR & 82 & 108 & 68 & $401 \mathrm{~B}$ & $1,190 \mathrm{~A}$ & $701 \mathrm{AB}$ & ${ }^{1} .0088$ & .0014 \\
\hline \multirow[t]{8}{*}{ Specific conductance } & DR & $87 \mathrm{~A}$ & $82 \mathrm{AB}$ & $78 \mathrm{~B}$ & -- & -- & -- & .0018 & -- \\
\hline & FB & $196 \mathrm{~A}$ & $178 \mathrm{~B}$ & $170 \mathrm{~B}$ & -- & -- & -- & .0061 & -- \\
\hline & M1 & $360 \mathrm{~A}$ & $264 \mathrm{~B}$ & 294 B & -- & -- & -- & .0014 & -- \\
\hline & M2 & $414 \mathrm{~A}$ & $329 \mathrm{~B}$ & $314 \mathrm{~B}$ & -- & -- & -- & .0001 & -- \\
\hline & M3 & 362 & 355 & 322 & -- & -- & -- & ${ }^{1} .0015$ & -- \\
\hline & M4 & $372 \mathrm{~A}$ & $324 \mathrm{~B}$ & $323 \mathrm{~B}$ & -- & -- & -- & .0002 & -- \\
\hline & WR & $348 \mathrm{~A}$ & $238 \mathrm{~B}$ & $310 \mathrm{AB}$ & -- & -- & -- & .0002 & -- \\
\hline & SR & $636 \mathrm{~A}$ & $698 \mathrm{~A}$ & $520 \mathrm{~B}$ & -- & -- & -- & .0001 & -- \\
\hline
\end{tabular}

\footnotetext{
${ }^{1}$ Unequal group size. Too few observations in one or more groups for meaningful statistical results.
} 

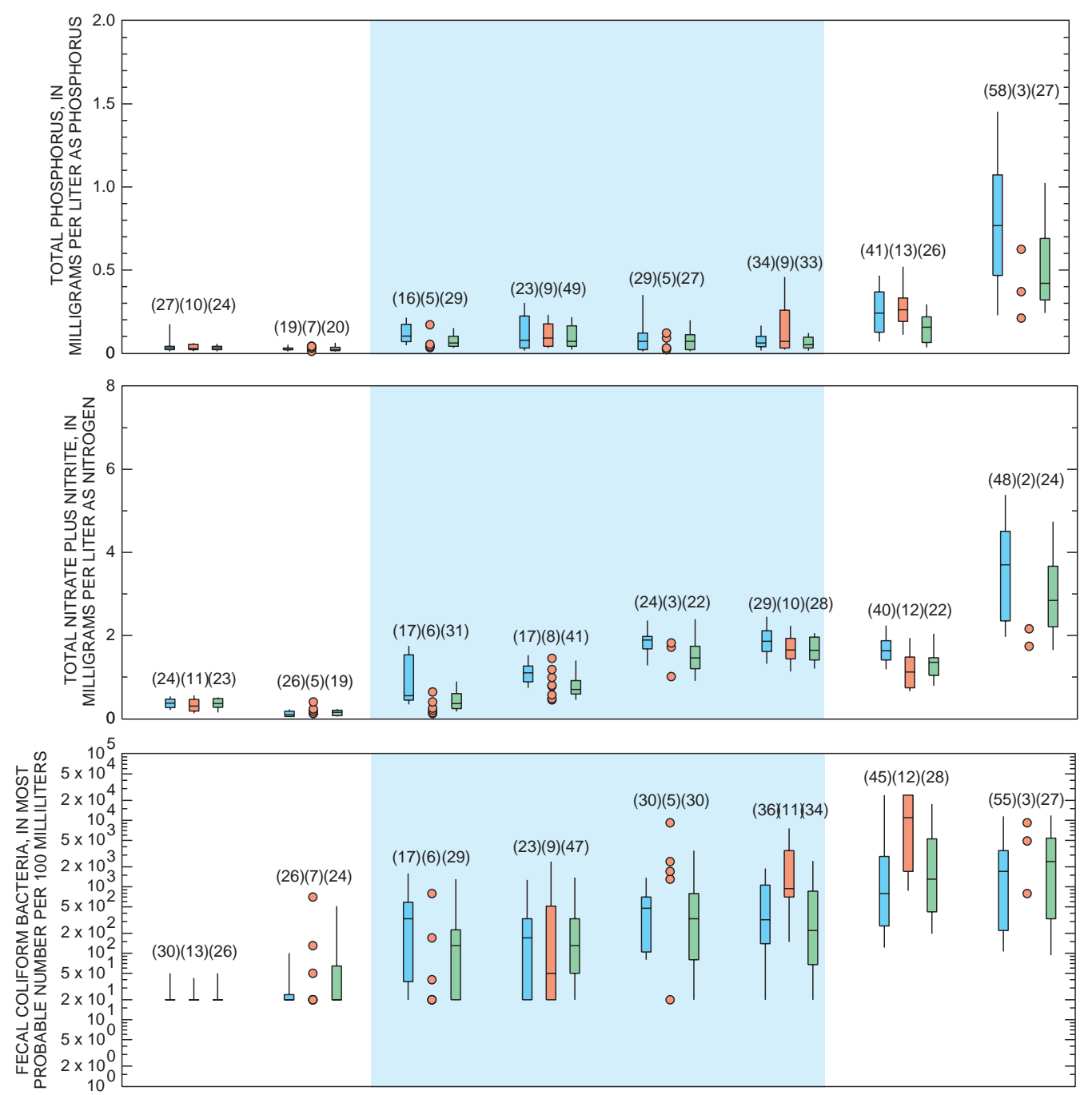

EXPLANATION

Before a storm

(27) Number of observations

Measured concentrations for nine or more observations

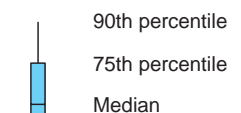

Median

25th percentile

10th percentile

O Measured concentrations for less than nine observations

During a storm

(10) Number of observations

Measured concentrations for nine or more observations

90th percentile

75th percentile

Median

25th percentile

10th percentile

O Measured concentrations for less than nine observations

After a storm

(24) Number of observations

Measured concentrations for nine or more observations

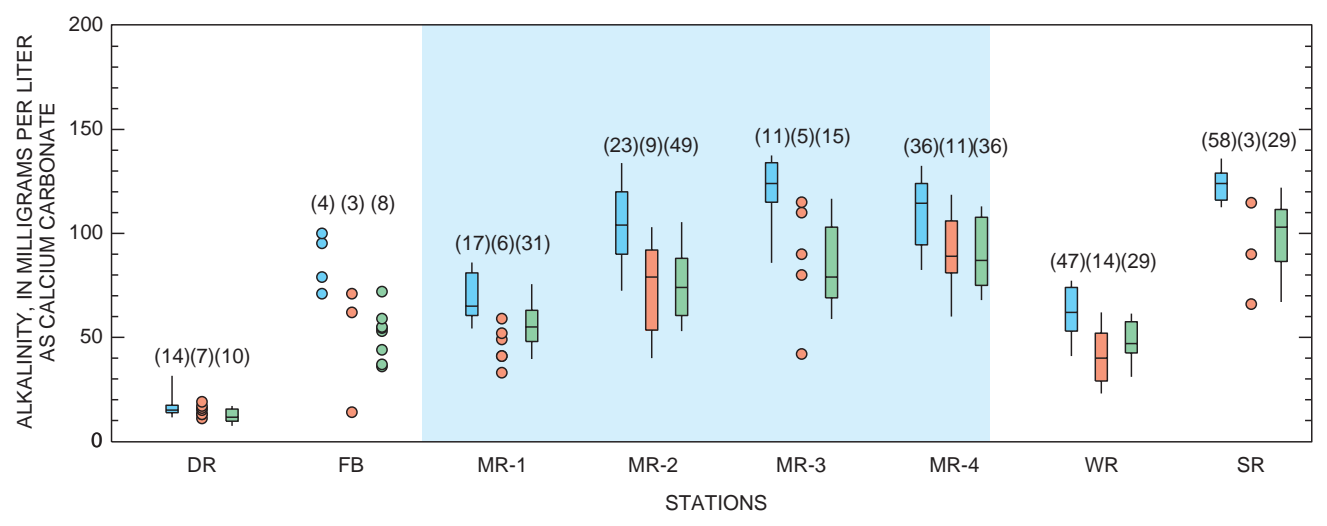

90th percentile

75th percentile

Median

25th percentile

10th percentile

- Measured concentrations for less than nine observations

WATER-QUALITY STATIONS

DR, Delaware River at Montague, N.J.

FB, Flat Brook at Flatbrookville, N.J.

MR1, Musconetcong River at Lockwood, N.J.

MR2, Musconetcong River at Beattystown, N.J.
MR3, Musconetcong River at Bloomsbury, N.J. MR4, Musconetcong River at Riegelsville, N.J.

WR, Whippany River at Morristown, N.J.

SR, Saddle River at Lodi, N.J.

Figure 5. Concentrations of selected water-quality constituents in samples collected before, during, and after a storm at water-quality stations on the Flat Brook and the Delaware, Musconetcong, Whippany, and Saddle Rivers, N.J., water years 1982-97. (Blue background indicates stations on the Musconetcong River. Stations are arranged from left to right in order of increasing land development in the areas contributing drainage and in downstream order on the Musconetcong River.) 

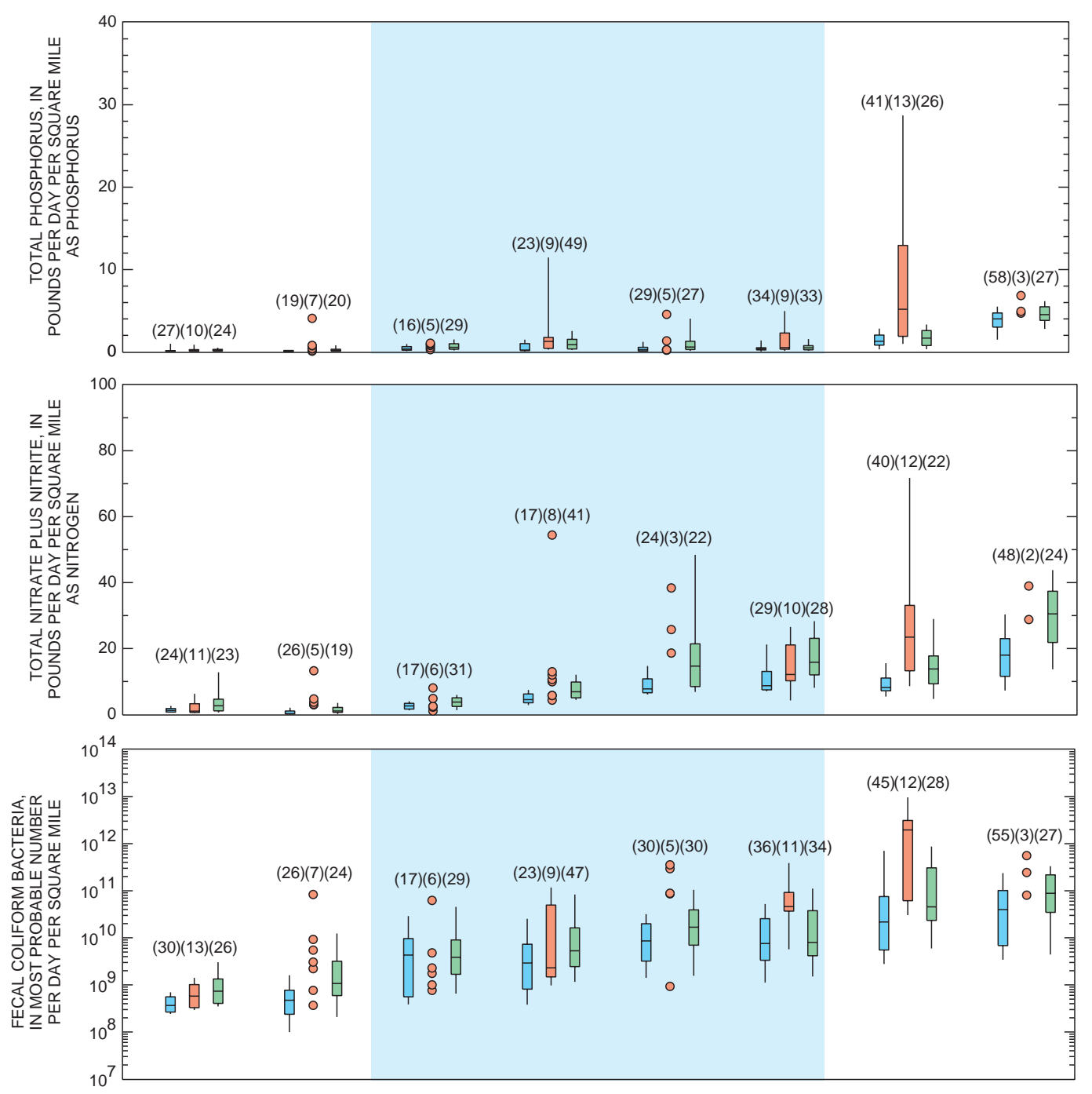

(27) Number of observations

Yields for nine or more observations



Median

25th percentile

10th percentile

Yields for less than nine observations

During a storm

(10) Number of observations

Yields for nine or more observations

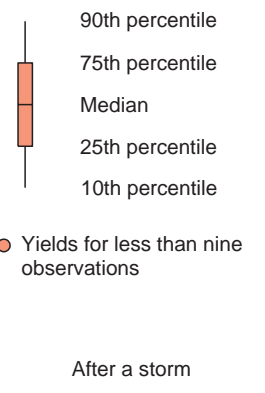

(24) Number of observations

Yields for nine or more observations
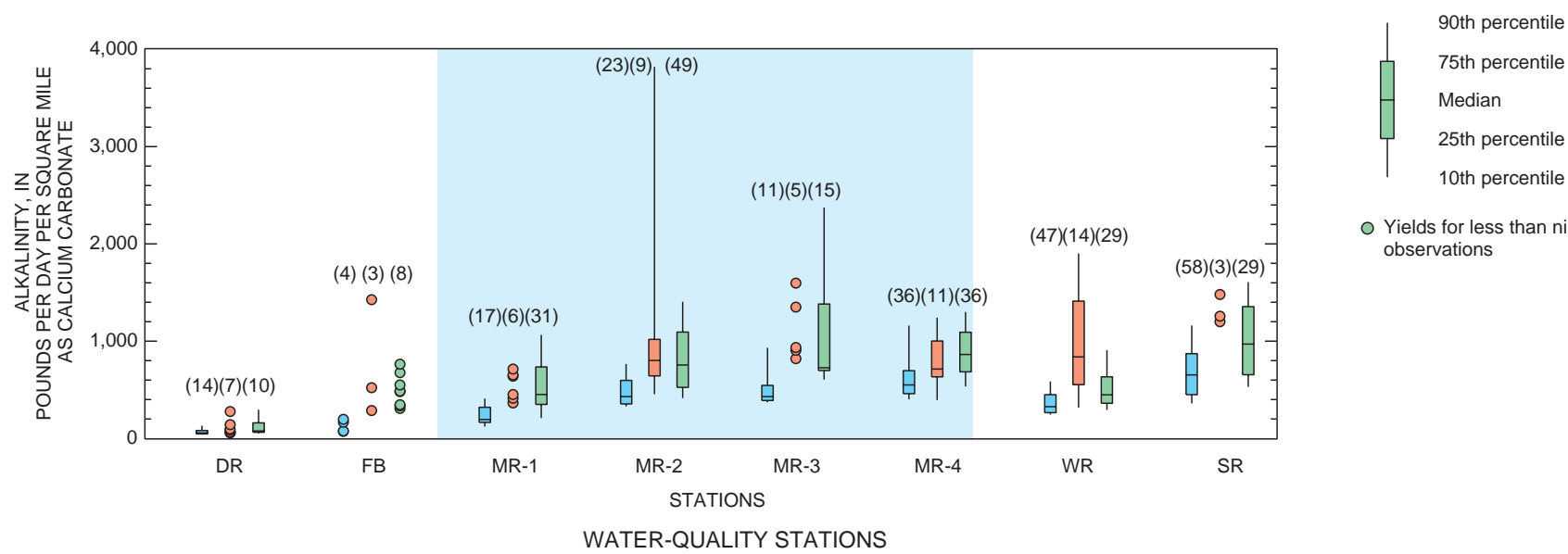

Yields for less than nine observations

DR, Delaware River at Montague, N.J. FB, Flat Brook at Flatbrookville, N.J.

MR3, Musconetcong River at Bloomsbury, N.J. MR1, Musconetcong River at Lockwood, N.J. MR2, Musconetcong River at Beattystown, N.J. MR4, Musconetcong River at Riegelsville, N.J. WR, Whippany River at Morristown, N.J. SR, Saddle River at Lodi, N.J.

Figure 6. Yields of selected water-quality constituents in samples collected before, during, and after a storm at water-quality stations on the Flat Brook and the Delaware, Musconetcong, Whippany, and Saddle Rivers, N.J., water years 1982-97. (Blue background indicates stations on the Musconetcong River. Stations are arranged from left to right in order of increasing land development in the areas contributing drainage and in downstream order on the Musconetcong River.) 
observed for total nitrogen because nitrate plus nitrite constitutes a high percentage of total nitrogen in most of these streams.

Concentrations of total nitrate plus nitrite differed between base flow and stormflow at half the stations (table 4) and were similar during, before, and after a storm at most stations (table 5) when analyzed by using the Kruskal-Wallis test. Concentrations were higher during base flow than stormflow at stations M1, M2, M3, and WR (table 4) and were higher before a storm than during or after a storm at stations M1 and WR (table 5) when analyzed by using the Tukey test. Yields of total nitrate plus nitrite at many stations differed (1) during base flow and stormflow and (2) during, before, and after a storm when analyzed by using the Kruskal-Wallis test (tables 3 and 4). Yields were significantly higher during stormflow than base flow at all stations except DR and M1 (table 4) and were higher during a storm than before a storm at stations FB, M2, M3, and WR (table 5) when analyzed by using the Tukey test.

At stations on the Flat Brook, and the Musconetcong and Whippany Rivers, yields of nitrate plus nitrite were affected more by contributions from storm runoff than by contributions from point sources (where present) and ground-water discharge. Yields at stations FB, M2, M3, M4, and WR were significantly higher (1) during stormflow than base flow and (2) during a storm than before a storm, indicating that the loads carried by the streams at these stations increased significantly during runoff conditions. At station DR and the most upstream station on the Musconetcong River (M1), yields of nitrate plus nitrite were affected less by contributions from storm runoff than by contributions from point sources and ground-water discharge because yields were statistically similar (1) during stormflow and base flow and (2) before, during, and after a storm (table 4).

\section{$\underline{\text { Bacteria }}$}

Fecal-coliform bacteria are present in the intestine and feces of warm-blooded animals. The presence of high numbers of fecal-coliform bacteria in surface water can indicate the recent release of untreated wastewater or the presence of animal feces, or both. These organisms also can indicate the presence of pathogens that are harmful to humans. High numbers of fecal-coliform bacteria can render surface water unfit for some uses, such as swimming and fishing.

Concentrations and yields of fecalcoliform bacteria during each flow condition differed among the eight stations when analyzed by using the Tukey test (table 3 ). In general, concentrations and yields were higher at stations SR, WR, M3, and M4, which drain areas with major development than at stations DR, FB, M1, and M2, which drain areas with little development.

Concentrations of fecal-coliform bacteria in samples collected during each flow condition were low, especially at stations FB and DR; those on the Musconetcong River were lower than those at stations WR and SR. Median concentrations ranged from 20 to $11,100 \mathrm{MPN} / 100 \mathrm{~mL}$, and median yields ranged from $3.70 \times 10^{8}$ to $1.96 \times 10^{12}(\mathrm{MPN} / \mathrm{d}) / \mathrm{mi}^{2}$ (tables 4 and 5). The distributions of fecal-coliform bacteria concentrations and yields in samples collected before, during, and after a storm are presented in box plots in figures 5 and 6 . Concentrations generally increased with an increase in the intensity of land development in the areas contributing drainage.

Concentrations of fecal-coliform bacteria were similar during base flow and stormflow at all stations and differed before, during, and after a storm at only one station when analyzed by using the Kruskal-Wallis test (tables 4 and 5). Concentrations before a storm were higher than during or after a storm at the WR station when analyzed by using the Tukey test (table 5). Yields of fecalcoliform bacteria at stations on streams draining either highly developed or undeveloped basins differed (1) during base flow and stormflow and (2) before, during, and after a storm when analyzed by using the Kruskal-Wallis test (tables 4 and 5). Yields were higher during stormflow than during base flow at the DR, FB, WR, and SR stations (table 4) and were higher during a storm than before or after a storm at the M4 station (table 5) when analyzed by using the Tukey test. Yields at stations FB and WR were significantly higher during a storm than before a storm. 
At stations DR, FB, and WR, yields of fecal-coliform bacteria were affected more by contributions from storm runoff than by contributions from point sources (where present) and groundwater discharge. Yields at stations DR, FB, and WR were significantly higher (1) during stormflow than base flow and (2) during a storm than before a storm, indicating that the loads carried by the streams at these stations increased significantly during runoff conditions. At the three upstream stations on the Musconetcong River (M1, M2, and M3), yields of fecal-coliform bacteria were affected less by contributions from storm runoff than by contributions from point sources (where present) and ground-water discharge; yields at these stations were similar (1) during stormflow and base flow and (2) before, during, and after a storm.

\section{$\underline{\text { Alkalinity and pH }}$}

Alkalinity is a measure of the capacity of water to neutralize acids and is the sum of all the titratable bases (mostly carbonate, bicarbonate, and hydroxides) in solution (Eaton and others, 1995). Alkalinity measurements are important in the evaluation and control of potable water and wastewater processes. In surface water that supports extensive algal blooms, consumption of carbon dioxide by algae for photosynthesis causes an increase in $\mathrm{pH}$ because of a shift in the forms of alkalinity, although total alkalinity does not change (Sawyer and McCarty, 1978). The $\mathrm{pH}$ of a solution is defined as the negative base-10 logarithm of the hydrogen-ion activity in moles per liter. Values of $\mathrm{pH}$ less than 7 indicate acidic conditions, and those higher than 7 indicate alkaline conditions.

During each flow condition, alkalinity concentrations differed among the eight stations when analyzed by using the Tukey test (table 3 ). Concentrations were highest and similar at stations SR, M4, and M3; lower and similar at stations WR, $\mathrm{M} 1$, and FB; and lowest at station DR. Concentrations increased in the downstream direction on the Musconetcong River. Alkalinity yields also differed among the eight stations during each flow condition when analyzed by using the Tukey test (table 3), and the pattern of differences in concen- trations and yields among the stations also was similar.

Median concentrations of alkalinity in samples collected during each flow condition were lowest at station DR where they ranged from 12 to $20 \mathrm{mg} / \mathrm{L}$; at all other stations, median alkalinity concentrations ranged from 40 to $124 \mathrm{mg} / \mathrm{L}$ (tables 4 and 5). Median values of alkalinity yields were lowest at station DR where they ranged from 57 to $87(\mathrm{lb} / \mathrm{d}) / \mathrm{mi}^{2}$; at all other stations, medians ranged from 121 to $1,257(\mathrm{lb} / \mathrm{d}) / \mathrm{mi}^{2}$ (tables 4 and 5). The distributions of alkalinity concentrations and yields in samples collected before, during, and after a storm are presented in box plots in figures 5 and 6 . Alkalinity concentrations and yields generally increased with increasing intensity of land development in the areas contributing drainage.

At all stations except DR, concentrations and yields of alkalinity differed during base flow and stormflow when analyzed by using the Kruskal-Wallis test (table 4); concentrations were highest during base flow, and yields were highest during stormflow when analyzed by using the Tukey test (table 4). At all stations except DR and $\mathrm{FB}$, concentrations and yields of alkalinity differed before, during, and after a storm when analyzed by using the Kruskal-Wallis test (table 5). Concentrations were higher before a storm than during and after a storm at all stations except DR and FB; yields were higher during and after a storm than before a storm at stations M1, M2, and M3 and higher during a storm than before and after a storm at station WR when analyzed by using the Tukey test (table 5).

At stations on the Musconetcong, Whippany, and Saddle Rivers, yields of alkalinity were affected more by contributions from storm runoff than by contributions from point sources and ground-water discharge. Yields at stations M1, M2, M3, M4, WR, and SR were significantly higher (1) during stormflow than base flow and (2) during a storm than before a storm (except at station M4), indicating that the loads carried by the streams at these stations increased significantly during runoff conditions (table 4). At station DR, yields of alkalinity were affected less by contributions from storm runoff than by contributions from point 
sources and ground-water discharge; yields were statistically similar (1) during stormflow and base flow and (2) before, during, and after a storm.

The $\mathrm{pH}$ was similar at all stations in samples collected during each flow condition--medians ranged from 7.5 to 8.2 (tables 4 and 5)--but statistically different when analyzed by using the Tukey test (table 3 ). Of the eight water-quality constituents studied, $\mathrm{pH}$ showed the least amount of variability between stations. Only at station WR did the $\mathrm{pH}$ significantly differ (1) between base flow and stormflow and (2) among before, during, and after a storm when analyzed by using the KruskalWallis test (tables 4 and 5); at this station, the $\mathrm{pH}$ was higher during base flow than stormflow and higher before a storm than during or after a storm when analyzed by using the Tukey test (tables 4 and 5). Except at station WR, contributions of $\mathrm{pH}$ from storm runoff were not significant in these streams because the $\mathrm{pH}$ was constant during changing streamflow. Although the alkalinity concentration decreased in these streams during stormflow, the buffering capacity in the river water was sufficient to minimize any change in the $\mathrm{pH}$ from the increased runoff. During increasing streamflow, the $\mathrm{pH}$ at station WR decreased and was similar to the $\mathrm{pH}$ before a storm at stations SR and DR, representing the most and least developed basins, respectively, in the study area.

\section{Chloride and Specific Conductance}

Important characteristics of chloride in surface waters are its ubiquitous presence in low concentrations and non-reactivity (Hem, 1985). Chloride is present in various rock types in concentrations lower than that of any of the other major constituents of ambient water. In streams that receive little point- or nonpoint-source contributions, chloride concentrations are low (generally less than $10 \mathrm{mg} / \mathrm{L}$ ) and are lower than those of sulfate or bicarbonate. Chloride ions move through a stream system mainly by physical processes (water inputs and withdrawals). Chloride does not enter into oxidation-reduction or biochemical reactions, form solute complexes or salts of low solubility, or absorb onto mineral surfaces. Important sources of chloride to a stream are ground-water inflow, point-source discharges of industrial wastewater that contain high concentrations of chloride, and runoff from storms and snow melt that contains dissolved chloride salts used for deicing roads. Specific conductance is related to the type and concentration of ions in solution and is inversely related to streamflow in streams in the study area (Buxton and others, 1999). (For the purposes of conciseness, specific conductance is listed in tables under concentrations.)

Median chloride concentrations ranged from 8.4 to $108 \mathrm{mg} / \mathrm{L}$, and median yields ranged from 29 to $1,190(\mathrm{lb} / \mathrm{d}) / \mathrm{mi}^{2}$. Median values of specific conductance ranged from 78 to $698 \mu \mathrm{S} / \mathrm{cm}$ in samples collected during all flow conditions (tables 4 and 5). Chloride concentrations and yields and specific conductance differed among the stations during all flow conditions when analyzed by using the Tukey test (table 3). Values at station SR, which drains a highly developed area, were higher than values at all other stations. Differences were greatest at stations DR and FB, which drain areas with little development. In general, chloride concentrations and yields, and specific conductance were similar at station WR and all stations along the Musconetcong River.

Chloride concentrations differed during base flow and stormflow at stations M1, M2, and SR (table 4) but were similar during, before, and after a storm at all stations (table 5) when analyzed by using the Kruskal-Wallis test. Concentrations were higher during base flow than stormflow at stations M1, M2, and SR when analyzed by using the Tukey test (table 4). Yields at all stations except DR differed (1) during base flow and stormflow and (2) before, during, and after a storm when analyzed by using the Kruskal-Wallis test (tables 3 and 4). Yields were higher during stormflow than base flow at all stations except DR (table 4) and were higher during and after a storm than before a storm at stations M1, M2, M3, and WR (table 5) when analyzed by using the Tukey test. Yields also were higher during a storm than before a storm at stations FB and WR.

At all stations except station DR, yields of chloride were affected more by contributions from storm runoff than by contributions from point 
sources (where present) and ground-water discharge. Yields at stations FB, M1, M2, M3, M4, WR, and SR were significantly higher (1) during stormflow than base flow and (2) during a storm than before a storm, indicating that the loads carried by the streams at these stations increased significantly during runoff conditions. At station DR, yields of chloride were affected less by contributions from storm runoff than by contributions from point sources and ground-water discharge because yields were similar (1) during stormflow and base flow and (2) before, during, and after a storm.

Storm runoff significantly reduced the specific conductance in all streams in the study area. Specific conductance values at all stations differed during base flow and stormflow when analyzed by using the Kruskal-Wallis test (table 4); values were higher during base flow than stormflow when analyzed by using the Tukey test (table 4). Specific conductance values at all stations except station M3 differed before, during, and after a storm when analyzed by using the Kruskal-Wallis test (table 5); values at stations FB, M1, M2, M4, and WR were higher before a storm than during or after a storm when analyzed by using the Tukey test (table 5). Specific conductance was significantly lower after a storm than before or during a storm.

\section{COMPARISONS OF WATER QUALITY DURING LOW, MEDIUM, AND HIGH STREAMFLOWS}

Streamflow condition can greatly affect the water quality of a stream. Instream concentrations of water-quality constituents are affected by streamflow because the contributions from storm runoff are flow dependent, whereas the contributions from point sources and ground-water discharge are relatively constant. Samples collected during low-flow conditions (collected when the instantaneous streamflows were equal to or less than the 75-percent flow-duration value) most likely were collected during base flow or before a storm; likewise, samples collected during highflow conditions (collected when the instantaneous streamflows were equal to or higher than the 25percent flow-duration value) most likely were col- lected during storm conditions. Samples collected during medium-flow conditions (samples collected when the instantaneous streamflows were less than the 25-percent flow-duration value and higher than the 75-percent flow-duration value) could have been collected during moderately high base-flow conditions, during moderate storms, or during rising or falling streamflows. Rainfall between 0.5 and 1.0 inch in 24 hours would result in measureable amounts of surface-water runoff.

Yields of water-quality constituents were affected more by contributions from storm runoff than by contributions from point sources and ground-water discharge in streams where yields were significantly higher during runoff conditions (high flows) than during non-runoff conditions (low or medium flows). In such cases, concentrations during high flows might be higher than during low or medium flows. Yields of water-quality constituents were affected less by contributions from storm runoff than by contributions from point sources and ground-water discharge in streams where yields during high flows were equal to or lower than during low or medium flows. In such cases, concentrations during high flows would be lower than during low or medium flows. Storm runoff could be an important contributor to streams even when concentrations during high flows were lower than during low or medium flows because the stream could be transporting higher masses (that is, total amounts) of constituents in the high streamflows associated with storm runoff.

In this section, results of statistical tests are discussed by water-quality constituent--nutrients (total phosphorus, nitrogen, and nitrate plus nitrite), fecal-coliform bacteria, alkalinity, $\mathrm{pH}$, chloride, and specific conductance. Two comparisons of water quality (for concentrations and yields) during various streamflow conditions at eight stations are presented. For the first comparison--to determine differences in water quality among the streams--differences in concentrations and yields during low, medium, and high flows among the stations are discussed. For the second comparison--to evaluate the relative importance of storm runoff at each station--differences in concentrations and yields during low, medium, and high flows at each station are discussed. 


\section{$\underline{\text { Nutrients }}$}

Both concentrations and yields of total phosphorus, nitrogen, and nitrate plus nitrite differed at the eight stations during low, medium, and high flows when analyzed by using the Tukey test (table 3). The general pattern of these differences is similar during each streamflow condition; stations on streams that drain areas with major development (SR and WR) had higher concentrations and yields than stations on streams that drain areas with little development (DR and FB). Concentrations and yields at station WR generally were lower than at station SR and higher than at the stations on the other streams. Concentrations and yields differed for each constituent at stations along the Musconetcong River (M1, M2, M3, and M4).

Concentrations of total phosphorus in all samples collected during low, medium, and high flows were low, especially at stations FB, DR, and those on the Musconetcong River. Median concentrations ranged from 0.02 to $1.02 \mathrm{mg} / \mathrm{L}$, and median yields ranged from 0.05 to $4.92(\mathrm{lb} / \mathrm{d}) / \mathrm{mi}^{2}$ (table 6). Median concentrations exceeded the 0.1 $\mathrm{mg} / \mathrm{L}$ NJDEP surface-water standard for phosphorus (New Jersey Department of Environmental Protection, 1998) at stations WR and SR during all flow conditions and at station M1 during low flow.

The distributions of total phosphorus concentrations and yields in samples collected during low, medium, and high flows are presented in box plots in figures 7 and 8. In general, concentrations and yields of total phosphorus during each streamflow condition were highest at station SR and lowest at stations FB and DR. The difference in the concentrations at each station was greater during low flow than high flow, whereas the difference in yields was greater during high flow than low flow when analyzed by using the Tukey test (table 3 ). Concentrations and yields were similar among the stations on the Musconetcong River during low, medium, and high flows.

Concentrations of total phosphorus differed at stations WR and SR, and yields differed at all stations except station SR during low, medium, and high flows when analyzed by using the Kruskal-Wallis test (table 6); yields were higher during high flows than low and medium flows at all stations except station SR when analyzed by using the Tukey test. The concentrations at station SR were significantly higher during low flows than during medium or high flows.

At all stations except station SR, yields of total phosphorus were affected more by contributions from storm runoff than by contributions from point sources (where present) and ground-water discharge. Although values were low, yields of total phosphorus at stations DR, FB, M1, M2, M3, M4, and WR were highest during high flow, indicating that the loads of total phosphorus increased significantly during runoff conditions. At station SR, yields were affected less by contributions from storm runoff than by contributions from point sources and ground-water discharge because yields during low, medium, and high flows were similar, indicating that the load of phosphorus was fairly constant during changing streamflow. Point-source sewage-treatment plants are located upstream from stations on the Delaware, Musconetcong, Whippany, and Saddle Rivers but contribute a higher amount to the flow at station SR than at any of the other stations.

Median concentrations of total nitrogen in all samples collected during low, medium, and high flows ranged from 0.40 to $6.90 \mathrm{mg} / \mathrm{L}$, and median yield values ranged from 0.71 to $49.72(\mathrm{lb} / \mathrm{d}) / \mathrm{mi}^{2}$ (table 6). Concentrations and yields of total nitrogen in samples collected during low, medium, and high flows were strongly related to the amount of development in each drainage basin; values were highest at station SR and lowest at stations FB and DR when analyzed by using the Tukey test (table 3 ). Concentrations and yields increased in the downstream direction along the Musconetcong River during medium and high flows. As observed for total phosphorus, the difference in the concentrations of total nitrogen at the stations is higher during low flow than high flow, whereas the difference in the yields at the stations is higher during high flow than low flow when analyzed by using the Tukey test (table 3).

Concentrations of total nitrogen at stations SR and WR and the two downstream stations on the Musconetcong River (M1 and M2) differed 
during low, medium, and high flows when analyzed by using the Kruskal-Wallis test (table 6); concentrations at stations M1, M2, WR, and SR were highest during low flow when analyzed by using the Tukey test. Yields at all stations differed during low, medium, and high flows when analyzed by using the Kruskal-Wallis test (table 6); yields were highest during high flows when analyzed by using the Tukey test.

At all stations on the Flat Brook and the Delaware, Musconetcong, Whippany, and Saddle Rivers, yields of total nitrogen were affected more by contributions from storm runoff than by contributions from point sources (where present) and ground-water discharge. Yields at stations FB, DR, M1, M2, M3, M4, WR, and SR were highest during high flows, indicating that the loads carried by these streams increased significantly during runoff conditions.

Median concentrations of nitrate plus nitrite ranged from 0.05 to $3.94 \mathrm{mg} / \mathrm{L}$, and median yield values ranged from 0.13 to $38.24(\mathrm{lb} / \mathrm{d}) / \mathrm{mi}^{2}$ during low, medium, and high flows (table 6). The distributions of nitrate plus nitrite concentrations and yields in samples collected during low, medium, and high flows are presented in box plots in figures 7 and 8 . The differences in concentrations and yields of nitrate plus nitrite among the stations is similar to that observed for total nitrogen when analyzed by using the Tukey test (table 3 ) because nitrate plus nitrite is a high percentage of total nitrogen in most of these streams, and concentrations and yields of nitrogen were strongly related to the amount of development in each drainage basin.

Concentrations of total nitrate plus nitrite at all stations except station DR differed during low, medium, and high flows when analyzed by using the Kruskal-Wallis test (table 6). Concentrations at stations M1 and WR were higher during low flow than during medium and high flows; concentrations at stations M2 and M3, which were similar during low and medium flows, were higher than during high flow when analyzed by using the Tukey test (table 6). Yields of total nitrate plus nitrite at all stations except station M2 differed during low, medium, and high flows when analyzed by using the Kruskal-Wallis test (table 6). Yields at stations DR, FB, M1, M3, M4, and WR were highest during high flows when analyzed by using the Tukey test. At station SR, yields, which were similar during medium and high flows, were higher than during low flow (table 6).

At stations on the Flat Brook, and Delaware, Musconetcong, Whippany, and Saddle Rivers, yields of nitrate plus nitrite were affected more by contributions from storm runoff than by contributions from point sources (where present) and ground-water discharge. Yields at all stations except the station on the Musconetcong River at Beattystown (M2) were highest during high flows, indicating that the loads carried by the streams at these stations increased significantly during runoff conditions. Yields at station SR also were similar during medium and high flows and were higher than during low flows. At station M2, yields of nitrate plus nitrite were affected less by contributions from storm runoff than by contributions from point sources and ground-water discharge because yields were similar during low, medium, and high flows.

\section{Bacteria}

Concentrations and yields of fecalcoliform bacteria during low, medium, and high flows differed among the eight stations when analyzed by using the Tukey test (table 3). In general, concentrations and yields at stations SR, WR, M3, and M4, which drain areas with substantial development, were higher than at stations DR, FB, M1, and M2, which drain areas with little development. The differences among the stations were greater during high flows than low flows. Concentrations of fecal-coliform bacteria in all samples were low, especially at stations FB and DR. Concentrations at stations on the Musconetcong River were lower than at stations WR and SR but higher than at stations FB and DR. Median concentrations for all stations ranged from 20 to $3,650 \mathrm{MPN} / 100 \mathrm{~mL}$, and median yields ranged from $2.70 \times 10^{8}$ to $4.00 \times 10^{11}(\mathrm{MPN} / \mathrm{d}) / \mathrm{mi}^{2}$ (table 6$)$. The distributions of fecal-coliform bacteria concentrations and yields in samples collected during low, medium, and high flows are presented in box plots in figures 7 and 8 . 
Table 6. Median concentrations and yields of selected constituents and results of the Tukey and Kruskal-Wallis tests to determine statistical differences among samples collected during low, medium, and high streamflows at each water-quality station on the Flat Brook and the Delaware, Musconetcong, Whippany, and Saddle Rivers, New Jersey, water years 1982-97

[DR, Delaware River at Montague; FB, Flat Brook at Flatbrookville; M1, Musconetcong River at Lockwood; M2, Musconetcong River at Beattystown; M3, Musconetcong River near Bloomsbury; M4, Musconetcong River at Riegelsville; WR, Whippany River at Morristown; SR, Saddle River at Lodi; differing letters indicate significant differences in median concentrations or yields at the 0.05 significance level, according to the Tukey test, where A is larger and B is smaller; all concentrations are in milligrams per liter, except for specific conductance which is in microsiemens per centimeter at 25 degrees Celsius and bacteria which are in most probable number per 100 milliliters; yields are in pounds per day per square mile, except for bacteria which are in most probable number per day per square mile; bold type indicates $p$ value is less than 0.05 , according to the Kruskal-Wallis tesshading $\mathrm{g}$ indicates $\mathrm{p}$ value is less than 0.01 , according to the Kruskal-Wallis test; --, no value determined]

\begin{tabular}{|c|c|c|c|c|c|c|c|c|c|}
\hline \multirow[b]{3}{*}{$\begin{array}{c}\text { Water-quality } \\
\text { constituent }\end{array}$} & \multirow{3}{*}{$\begin{array}{l}\text { Water- } \\
\text { quality } \\
\text { station }\end{array}$} & \multicolumn{6}{|c|}{ Tukey test } & \multirow{2}{*}{\multicolumn{2}{|c|}{$\begin{array}{c}\text { Kruskal-Wallis } \\
\text { test, } \\
\text { p-value }\end{array}$}} \\
\hline & & \multicolumn{3}{|c|}{ Median concentration } & \multicolumn{3}{|c|}{ Median yield } & & \\
\hline & & Low flow & Medium flow & High flow & Low flow & Medium flow & High flow & $\begin{array}{l}\text { Concen- } \\
\text { tration }\end{array}$ & Yield \\
\hline \multirow[t]{8}{*}{ Total phosphorus } & DR & 0.03 & 0.03 & 0.03 & $0.08 \mathrm{~B}$ & $0.14 \mathrm{~B}$ & $0.34 \mathrm{~A}$ & 0.9967 & 0.0001 \\
\hline & FB & .02 & .02 & .03 & $.05 \mathrm{C}$ & $.15 \mathrm{~B}$ & $.69 \mathrm{~A}$ & .3731 & .0001 \\
\hline & M1 & .10 & .07 & .06 & $.20 \mathrm{C}$ & $.46 \mathrm{~B}$ & $1.02 \mathrm{~A}$ & .2349 & .0001 \\
\hline & M2 & .08 & .07 & .08 & $.21 \mathrm{~B}$ & $.50 \mathrm{~B}$ & $1.45 \mathrm{~A}$ & .5227 & .0002 \\
\hline & M3 & .09 & .04 & .07 & $.34 \mathrm{~B}$ & $.28 \mathrm{~B}$ & $1.32 \mathrm{~A}$ & .5145 & .0006 \\
\hline & M4 & .05 & .06 & .05 & $.19 \mathrm{C}$ & $.44 \mathrm{~B}$ & $.97 \mathrm{~A}$ & .7898 & .0003 \\
\hline & WR & $.34 \mathrm{~A}$ & $.18 \mathrm{AB}$ & $.17 \mathrm{AB}$ & $1.30 \mathrm{~B}$ & $1.12 \mathrm{~B}$ & $3.34 \mathrm{~A}$ & .0008 & .0001 \\
\hline & SR & $1.02 \mathrm{~A}$ & $.52 \mathrm{~B}$ & $.30 \mathrm{~B}$ & 3.91 & 4.25 & 4.92 & .0001 & .1196 \\
\hline \multirow{8}{*}{ Total nitrogen } & DR & .66 & .66 & .78 & $1.91 \mathrm{~B}$ & $2.97 \mathrm{~B}$ & $12.57 \mathrm{~A}$ & .2075 & .0001 \\
\hline & FB & .40 & .43 & .47 & $.71 \mathrm{~B}$ & $2.80 \mathrm{~B}$ & $7.43 \mathrm{~A}$ & .1838 & .0001 \\
\hline & M1 & $2.46 \mathrm{~A}$ & $1.41 \mathrm{~B}$ & $.88 \mathrm{C}$ & $5.06 \mathrm{C}$ & $8.18 \mathrm{~B}$ & $14.44 \mathrm{~A}$ & .0001 & .0001 \\
\hline & M2 & $1.92 \mathrm{~A}$ & $1.60 \mathrm{AB}$ & $1.21 \mathrm{~B}$ & $5.71 \mathrm{C}$ & $11.79 \mathrm{~B}$ & $21.31 \mathrm{~A}$ & .0003 & .0001 \\
\hline & M3 & 2.25 & 2.06 & 1.89 & $8.21 \mathrm{C}$ & $14.27 \mathrm{~B}$ & $46.53 \mathrm{~A}$ & .1314 & .0001 \\
\hline & M4 & 3.06 & 2.57 & 2.11 & $9.47 \mathrm{C}$ & $17.27 \mathrm{~B}$ & $35.79 \mathrm{~A}$ & .0225 & .0001 \\
\hline & WR & $2.69 \mathrm{~A}$ & $2.13 \mathrm{~B}$ & $1.80 \mathrm{C}$ & $9.62 \mathrm{C}$ & $16.86 \mathrm{~B}$ & $46.49 \mathrm{~A}$ & .0002 & .0001 \\
\hline & SR & $6.90 \mathrm{~A}$ & $5.07 \mathrm{~B}$ & $3.30 \mathrm{C}$ & $27.05 \mathrm{C}$ & $37.83 \mathrm{~B}$ & $49.72 \mathrm{~A}$ & .0001 & .0001 \\
\hline \multirow[t]{8}{*}{ Nitrate plus nitrite } & DR & .35 & .32 & .37 & $.92 \mathrm{~B}$ & $1.57 \mathrm{~B}$ & $6.13 \mathrm{~A}$ & .2204 & .0001 \\
\hline & FB & $.05 \mathrm{~B}$ & $.16 \mathrm{~A}$ & $.18 \mathrm{~A}$ & $.13 \mathrm{C}$ & $1.02 \mathrm{~B}$ & $3.23 \mathrm{~A}$ & .0010 & .0001 \\
\hline & M1 & $1.54 \mathrm{~A}$ & $.45 \mathrm{~B}$ & $.24 \mathrm{C}$ & $2.80 \mathrm{~B}$ & $2.62 \mathrm{~B}$ & $4.49 \mathrm{~A}$ & .0001 & .0001 \\
\hline & M2 & $1.26 \mathrm{~A}$ & $.84 \mathrm{~A}$ & $.51 \mathrm{~B}$ & 3.26 & 6.19 & 9.97 & .0001 & .0180 \\
\hline & M3 & $1.92 \mathrm{~A}$ & $1.64 \mathrm{~A}$ & $1.20 \mathrm{~B}$ & $6.76 \mathrm{C}$ & $11.40 \mathrm{~B}$ & $25.77 \mathrm{~A}$ & .0013 & .0001 \\
\hline & M4 & $2.02 \mathrm{~A}$ & $1.77 \mathrm{AB}$ & $1.47 \mathrm{~B}$ & $7.09 \mathrm{C}$ & $11.68 \mathrm{~B}$ & $24.48 \mathrm{~A}$ & .0029 & .0001 \\
\hline & WR & $1.83 \mathrm{~A}$ & $1.45 \mathrm{~B}$ & $1.07 \mathrm{C}$ & $7.39 \mathrm{C}$ & $11.37 \mathrm{~B}$ & $27.10 \mathrm{~A}$ & .0001 & .0001 \\
\hline & SR & $3.94 \mathrm{~A}$ & $3.18 \mathrm{AB}$ & $2.24 \mathrm{~B}$ & $14.99 \mathrm{~B}$ & $23.66 \mathrm{~A}$ & $38.24 \mathrm{~A}$ & .0014 & .0001 \\
\hline \multirow[t]{8}{*}{ Fecal coliform bacteria } & DR & 20 & 20 & 20 & $2.70 \times 10^{8} \mathrm{~B}$ & $4.10 \times 10^{10} \mathrm{~B}$ & $1.40 \times 10^{9} \mathrm{~A}$ & .0103 & .0001 \\
\hline & FB & 20 & 20 & 20 & $2.40 \times 10^{8} \mathrm{C}$ & $2.90 \times 10^{10} \mathrm{~B}$ & $2.00 \times 10^{9} \mathrm{~A}$ & .9924 & .0001 \\
\hline & M1 & 295 & 170 & 40 & $2.90 \times 10^{9}$ & $2.90 \times 10^{10}$ & $2.30 \times 10^{9}$ & .0554 & .7458 \\
\hline & M2 & 200 & 130 & 60 & $2.30 \times 10^{9}$ & $4.90 \times 10^{10}$ & $6.70 \times 10^{9}$ & .2773 & .0870 \\
\hline & M3 & 490 & 490 & 170 & $8.00 \times 10^{9}$ & $3.10 \times 10^{10}$ & $2.40 \times 10^{10}$ & .2444 & .1335 \\
\hline & M4 & 410 & 490 & 170 & $6.10 \times 10^{9}$ & $4.90 \times 10^{10}$ & $1.10 \times 10^{10}$ & .1425 & .5043 \\
\hline & WR & 800 & 800 & 3,650 & $1.40 \times 10^{10} \mathrm{~B}$ & $3.80 \times 10^{10} \mathrm{~B}$ & $4.00 \times 10^{11} \mathrm{~A}$ & .0256 & .0001 \\
\hline & SR & $3,300 \mathrm{~A}$ & $790 \mathrm{~B}$ & $790 \mathrm{AB}$ & $5.70 \times 10^{10}$ & $3.50 \times 10^{10}$ & $4.80 \times 10^{10}$ & .0057 & .3029 \\
\hline \multirow[t]{8}{*}{ Alkalinity } & DR & 15 & 15 & 11 & $46 \mathrm{~B}$ & $71 \mathrm{~B}$ & $159 \mathrm{~A}$ & .0372 & .0001 \\
\hline & FB & $87 \mathrm{~A}$ & $57 \mathrm{~B}$ & $36 \mathrm{C}$ & $121 \mathrm{C}$ & $414 \mathrm{~B}$ & $763 \mathrm{~A}$ & .0047 & .0031 \\
\hline & M1 & $81 \mathrm{~A}$ & $59 \mathrm{~B}$ & $43 \mathrm{C}$ & $164 \mathrm{C}$ & $365 \mathrm{~B}$ & $735 \mathrm{~A}$ & .0001 & .0001 \\
\hline & M2 & $120 \mathrm{~A}$ & $84 \mathrm{~B}$ & $58 \mathrm{C}$ & $346 \mathrm{C}$ & $585 \mathrm{~B}$ & $1,107 \mathrm{~A}$ & .0001 & .0001 \\
\hline & M3 & $124 \mathrm{~A}$ & $103 \mathrm{~B}$ & $69 \mathrm{C}$ & $427 \mathrm{C}$ & $708 \mathrm{~B}$ & $1,382 \mathrm{~A}$ & .0001 & .0001 \\
\hline & M4 & $128 \mathrm{~A}$ & $101 \mathrm{~B}$ & $74 \mathrm{C}$ & $406 \mathrm{C}$ & $680 \mathrm{~B}$ & $1,156 \mathrm{~A}$ & .0001 & .0001 \\
\hline & WR & $73 \mathrm{~A}$ & $54 \mathrm{~B}$ & $38 \mathrm{C}$ & $260 \mathrm{C}$ & $429 \mathrm{~B}$ & $901 \mathrm{~A}$ & .0001 & .0001 \\
\hline & SR & $124 \mathrm{~A}$ & $116 \mathrm{~A}$ & $92 \mathrm{~B}$ & $484 \mathrm{C}$ & $876 \mathrm{~B}$ & $1,470 \mathrm{~A}$ & .0001 & .0001 \\
\hline
\end{tabular}


Table 6. Median concentrations and yields of selected constituents and results of the Tukey and Kruskal-Wallis tests to determine statistical differences among samples collected during low, medium, and high streamflows at each water-quality station on the Flat Brook and the Delaware, Musconetcong, Whippany, and Saddle Rivers, New Jersey, water years 1982-97--Continued

\begin{tabular}{|c|c|c|c|c|c|c|c|c|c|}
\hline \multirow[b]{3}{*}{$\begin{array}{c}\text { Water-quality } \\
\text { constituent }\end{array}$} & \multirow{3}{*}{$\begin{array}{l}\text { Water- } \\
\text { quality } \\
\text { station }\end{array}$} & \multicolumn{6}{|c|}{ Tukey test } & \multirow{2}{*}{\multicolumn{2}{|c|}{$\begin{array}{c}\text { Kruskal-Wallis } \\
\text { test, } \\
\text { p-value }\end{array}$}} \\
\hline & & \multicolumn{3}{|c|}{ Median concentration } & \multicolumn{3}{|c|}{ Median yield } & & \\
\hline & & Low flow & Medium flow & High flow & Low flow & Medium flow & High flow & $\begin{array}{l}\text { Concen- } \\
\text { tration }\end{array}$ & Yield \\
\hline \multirow{8}{*}{$\mathrm{pH}$} & DR & 7.5 & 7.7 & 7.5 & -- & -- & -- & .1021 & -- \\
\hline & FB & 8.1 & 7.8 & 7.7 & -- & -- & -- & .0197 & -- \\
\hline & M1 & 7.8 & 7.7 & 7.8 & -- & -- & -- & .8879 & -- \\
\hline & M2 & 8.3 & 8.1 & 8.1 & -- & -- & -- & .2099 & -- \\
\hline & M3 & 8.3 & 8.2 & 7.8 & -- & -- & -- & .0111 & -- \\
\hline & M4 & 8.1 & 8.2 & 8.0 & -- & -- & -- & .1287 & -- \\
\hline & WR & $8.0 \mathrm{~A}$ & $7.9 \mathrm{~A}$ & $7.5 \mathrm{~B}$ & -- & -- & -- & .0001 & -- \\
\hline & SR & $7.6 \mathrm{~B}$ & $7.8 \mathrm{~A}$ & $7.7 \mathrm{AB}$ & -- & -- & -- & .0032 & -- \\
\hline \multirow[t]{8}{*}{ Chloride } & DR & $6.0 \mathrm{~B}$ & $9.6 \mathrm{~A}$ & $7.2 \mathrm{~B}$ & $18 \mathrm{~B}$ & $47 \mathrm{~B}$ & $114 \mathrm{~A}$ & .0008 & .0001 \\
\hline & FB & 15 & 14 & 10 & $22 \mathrm{~B}$ & $77 \mathrm{~B}$ & $204 \mathrm{~A}$ & .0116 & .0001 \\
\hline & M1 & $59 \mathrm{~A}$ & $44 \mathrm{~B}$ & $33 \mathrm{C}$ & $137 \mathrm{C}$ & $256 \mathrm{~B}$ & $628 \mathrm{~A}$ & .0001 & .0001 \\
\hline & M2 & 48 & 39 & 38 & $131 \mathrm{C}$ & $301 \mathrm{~B}$ & $838 \mathrm{~A}$ & .1140 & .0001 \\
\hline & M3 & 29 & 35 & 35 & $93 \mathrm{C}$ & $271 \mathrm{~B}$ & $755 \mathrm{~A}$ & .0643 & .0001 \\
\hline & M4 & 26 & 29 & 26 & $86 \mathrm{C}$ & $191 \mathrm{~B}$ & $448 \mathrm{~A}$ & .2420 & .0001 \\
\hline & WR & 44 & 49 & 34 & $161 \mathrm{C}$ & $347 \mathrm{~B}$ & $844 \mathrm{~A}$ & .0135 & .0001 \\
\hline & SR & 82 & 77 & 68 & $308 \mathrm{C}$ & $590 \mathrm{~B}$ & $1,121 \mathrm{~A}$ & .2976 & .0001 \\
\hline \multirow[t]{8}{*}{ Specific conductance } & DR & $86 \mathrm{~A}$ & $83 \mathrm{~A}$ & $69 \mathrm{~B}$ & -- & -- & -- & .0001 & -- \\
\hline & FB & $234 \mathrm{~A}$ & $181 \mathrm{~B}$ & $134 \mathrm{C}$ & -- & -- & -- & .0001 & -- \\
\hline & M1 & $414 \mathrm{~A}$ & $315 \mathrm{~B}$ & $240 \mathrm{C}$ & -- & -- & -- & .0001 & -- \\
\hline & M2 & $456 \mathrm{~A}$ & $336 \mathrm{~B}$ & $282 \mathrm{C}$ & -- & -- & -- & .0001 & -- \\
\hline & M3 & $368 \mathrm{~A}$ & $340 \mathrm{~A}$ & $310 \mathrm{~B}$ & -- & -- & -- & .0003 & -- \\
\hline & M4 & $398 \mathrm{~A}$ & $344 \mathrm{~B}$ & $284 \mathrm{C}$ & -- & -- & -- & .0001 & -- \\
\hline & WR & $357 \mathrm{~A}$ & $328 \mathrm{~A}$ & $247 \mathrm{~B}$ & -- & -- & -- & .0001 & -- \\
\hline & SR & $638 \mathrm{~A}$ & $597 \mathrm{AB}$ & $502 \mathrm{~B}$ & -- & -- & -- & .0025 & -- \\
\hline
\end{tabular}





EXPLANATION

Low flows

(13) Number of observations

Measured concentrations for nine or more observations

90th percentile

75th percentile

Median

25th percentile

10th percentile

- Measured concentrations for less than nine observations

Medium flows

(38) Number of observations

measured concentrations for nine or more observations

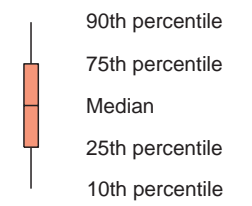

O Measured concentrations for less than nine observations

High flows

(10) Number of observations

Measured concentrations for nine or more observations
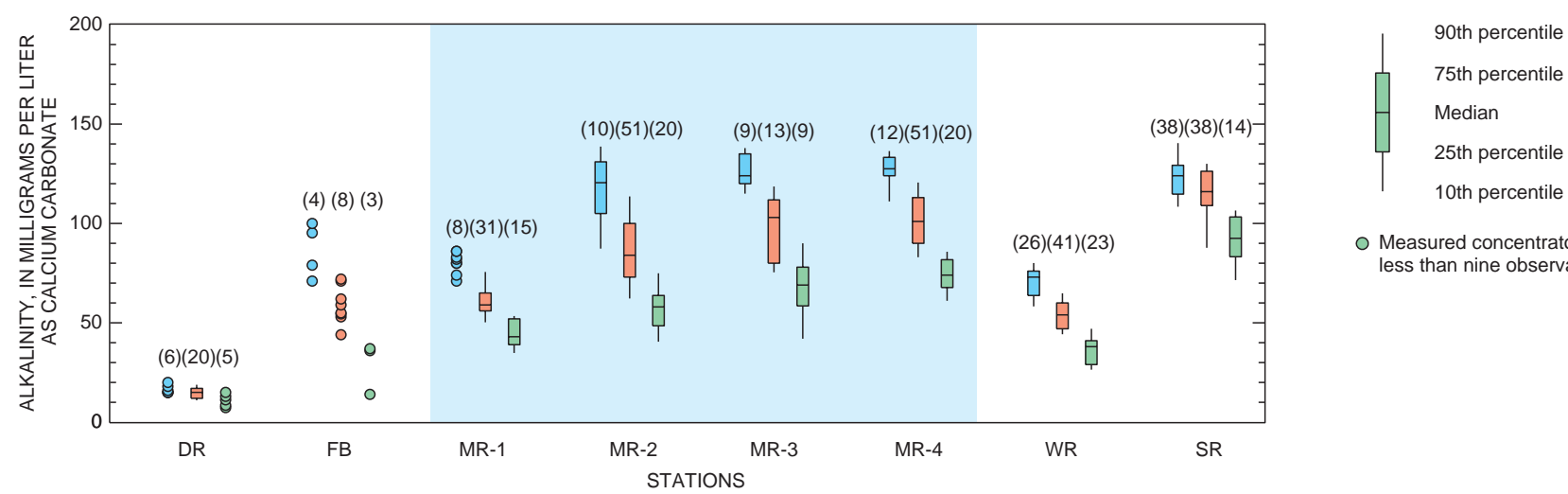

O Measured concentratons for less than nine observations

WATER-QUALITY STATIONS

DR, Delaware River at Montague, N.J. FB, Flat Brook at Flatbrookville, N.J. MR1, Musconetcong River at Lockwood, N.J. MR2, Musconetcong River at Beattystown, N.J.
MR3, Musconetcong River at Bloomsbury, N.J. MR4, Musconetcong River at Riegelsville, N.J. WR, Whippany River at Morristown, N.J. SR, Saddle River at Lodi, N.J.

Figure 7. Concentrations of selected water-quality constituents in samples collected during low, medium, and high flows at water-quality stations on the Flat Brook and the Delaware, Musconetcong, Whippany, and Saddle Rivers, N.J., water years 1982-97. (Blue background indicates stations on the Musconetcong River. Stations are arranged from left to right in order of increasing land development in the areas contributing drainage and in downstream order on the Musconetcong River.) 



EXPLANATION

Low flows

(13) Number of observations

Yields for nine or more observations

$$
\begin{aligned}
& \text { 90th percentile } \\
& \text { 75th percentile } \\
& \text { Median } \\
& \text { 25th percentile } \\
& \text { 10th percentile } \\
& \text { Yields for less than nine } \\
& \text { observations } \\
& \text { Meidum flows }
\end{aligned}
$$

(38) Number of observations

Yields for nine or more observations

\section{0th percentile \\ 75th percentile \\ Median \\ 25th percentile \\ 10th percentile}

Yields for less than nine observations

High flows

(10 Number of observations

Yields for nine or more observations
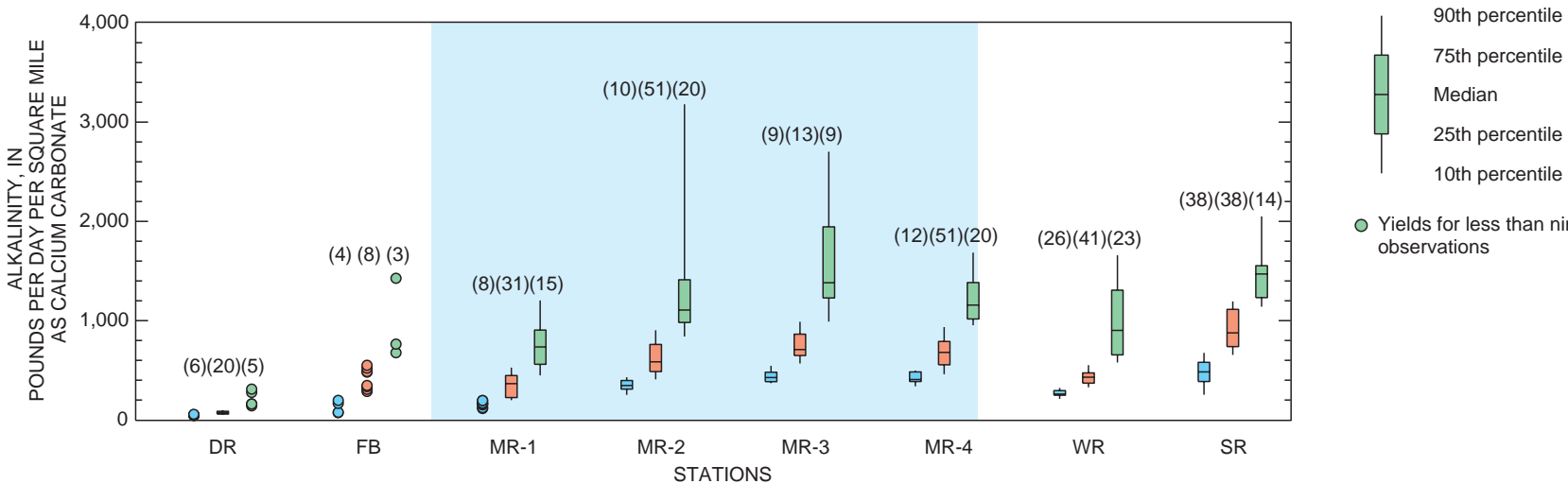

Yields for less than nine observations

Figure 8. Yields of selected water-quality constituents in samples collected during low, medium, and high flows at water-quality stations on the Flat Brook and the Delaware, Musconetcong, Whippany, and Saddle Rivers, N.J., water years 1982-97. (Blue background indicates stations on the Musconetcong River. Stations are arranged from left to right in order of increasing land development in the areas contributing drainage and in downstream order on the Musconetcong River.) 
Concentrations of fecal-coliform bacteria during low, medium, and high flows at each station differed only at station SR, and yields differed at stations DR, FB, and WR when analyzed by using the Kruskal-Wallis test (table 6). Yields were highest at stations DR, FB, and WR during high flow when analyzed by using the Tukey test (table 6). Concentrations were significantly higher during low flows than during medium flows at station SR.

At stations FB, DR, and WR, yields of fecal-coliform bacteria were affected more by contributions from storm runoff than by contributions from point sources (where present) and groundwater discharge. Yields at stations DR, FB, and WR were highest during high flows, indicating that the loads carried by the streams at these stations increased significantly during runoff conditions. At all stations on the Musconetcong River and station SR, yields of fecal-coliform bacteria were affected less by contributions from storm runoff than by contributions from point sources and ground-water discharge because yields were similar during low, medium, and high flows.

\section{$\underline{\text { Alkalinity and pH }}$}

Alkalinity concentrations and yields differed among the eight stations during low, medium, and high flows when analyzed by using the Tukey test (table 3 ). The differences among the stations were greatest during medium flows and least during low flows. During low, medium, and high flows, median alkalinity concentrations were lowest at station DR where they ranged from 11 to $15 \mathrm{mg} / \mathrm{L}$; at all other stations, median alkalinity concentrations ranged from 36 to $128 \mathrm{mg} / \mathrm{L}$ (table 6). Median alkalinity yields ranged from 46 to $1,470(\mathrm{lb} / \mathrm{d}) / \mathrm{mi}^{2}$ (table 6). The distributions of alkalinity concentrations and yields in samples collected during low, medium, and high flows are presented in box plots in figures 7 and 8 .
Alkalinity concentrations at all stations except station DR and yields at all stations differed during low, medium, and high flows when analyzed by using the Kruskal-Wallis test (table 6). Concentrations were highest during low flows at stations FB, M1, M2, M3, and M4 and highest during low and medium flows at station SR; yields were highest during high flows at all stations when analyzed by using the Tukey test (table 6 ).

At all stations on the Flat Brook, and the Delaware, Musconetcong, Whippany, and Saddle Rivers, yields of alkalinity were affected more by contributions from storm runoff than by contributions from point sources (where present) and ground-water discharge. Yields at all stations were highest during high flows, indicating that the loads carried by these streams increased significantly during runoff conditions (table 6).

The range of medium $\mathrm{pH}$ at the eight stations during low, medium, and high flows was small, from 7.5 to 8.3 (table 6), but statistically different when analyzed by using the Tukey test (table 3); differences among the stations were greatest during medium flows. The $\mathrm{pH}$ at stations DR, WR, and SR differed during low, medium, and high flows when analyzed by using the KruskalWallis test (table 6). The $\mathrm{pH}$ was higher during low and medium flows than during high flows at station WR, higher during medium flows than low flows at station SR, and higher during medium flows than low or high flows at station DR when analyzed by using the Tukey test (table 6). Contributions of $\mathrm{pH}$ from storm runoff were not significant for all the streams in this study because the $\mathrm{pH}$ varied little during changing streamflow. Although alkalinity decreased in these streams during stormflow, the buffering capacity of the river water was sufficient to minimize any change in the $\mathrm{pH}$ because of runoff at most stations. 


\section{Chloride and Specific Conductance}

During low, medium, and high flows, median chloride concentrations ranged from 6.0 to $82 \mathrm{mg} / \mathrm{L}$, and median yields ranged from 18 to $1,121(\mathrm{lb} / \mathrm{d}) / \mathrm{mi}^{2}$; median concentrations of specific conductance ranged from 69 to $638 \mu \mathrm{S} / \mathrm{cm}$ (table

6). Chloride concentrations and yields, and specific conductance differed among the eight stations during low, medium, and high flows when analyzed by using the Tukey test (table 3). Differences in chloride concentrations were greatest during medium flows, and differences in specific conductance were greatest during low flows. Values at station SR, which drains a highly developed area, were higher than values at stations DR and FB, which drain areas with little development. In the downstream direction on the Musconetcong River, concentrations of chloride decreased, whereas yields were variable but similar during each streamflow condition; concentrations were most different during medium flows and most similar during high flows. Specific conductance was similar at all stations along the Musconetcong River.

Chloride concentrations at stations DR and M1 differed during low, medium, and high flows when analyzed by using the Kruskal-Wallis test (table 6); concentrations were highest during medium flows at station DR and during low flows at station M1 when analyzed by using the Tukey test. Yields at all stations except station DR differed during low, medium, and high flows when analyzed by using the Kruskal-Wallis test (table 6); yields were highest during high flows when analyzed by using the Tukey test.

Stormflow reduced the specific conductance in all streams in the study area. Specific conductance values at all stations differed during low, medium, and high flows when analyzed by using the Kruskal-Wallis test (table 6). Values were highest during low flows at stations FB, M1, M2, and M4 and during low and medium flows at stations DR, M3, and WR when analyzed by using the Tukey test (table 6).

\section{COMPARISON OF CONTRIBUTIONS \\ OF SELECTED WATER-QUALITY CONSTITUENTS AT STATIONS ON THE FLAT BROOK, AND THE DELAWARE, MUSCONETCONG, WHIPPANY, AND SADDLE RIVERS}

To determine the relative importance of contributions of water-quality constituents from storm runoff and from point sources and groundwater discharge at the eight stations, differences were determined among yields (1) during base flow and stormflow (table 4); (2) before, during, and after a storm (table 5); and (3) during low, medium, and high flows (table 6) at each station. Runoff conditions were considered to occur (1) during stormflow, in the comparison of base flow and stormflow; (2) during a storm, in the comparison of before, during, and after a storm; and (3) during high flow, in the comparison of values during low, medium, and high flows. Likewise, nonrunoff conditions were considered to occur (1) during base flow, in the comparison of base flow and stormflow; (2) before a storm, in the comparison of before, during, and after a storm; and (3) during low flow, in the comparison of values during low, medium, and high flows.

If yields were significantly higher during runoff conditions than during non-runoff conditions in all three comparisons, indicating that the loads carried by the streams increased during runoff conditions, then yields were considered to be affected more by contributions from storm runoff than by contributions from point sources and ground-water discharge. If yields were significantly higher during runoff conditions than during non-runoff conditions in two of the three comparisons, then yields were considered most likely to be affected more by contributions from storm runoff than by contributions from point sources and ground-water discharge. If yields were similar during runoff and non-runoff conditions in two or all of the three comparisons, indicating that the loads in the streams were relatively constant during runoff conditions, then yields were considered to be affected less by contributions from storm runoff than by contributions from point sources and ground-water discharge. 
At the station on the Flat Brook, yields of most water-quality constituents were affected more by contributions from storm runoff than by contributions from ground-water discharge. Yields of total phosphorus, nitrogen, nitrate plus nitrite, fecal-coliform bacteria, and chloride were higher during runoff conditions than non-runoff conditions in each of the three comparisons. Yields of alkalinity were higher during runoff conditions than non-runoff conditions in two of the three comparisons.

At the station on the Delaware River, yields of fecal-coliform bacteria were affected more by contributions from storm runoff than by contributions from point sources and ground-water discharges; yields were higher during runoff conditions than non-runoff conditions in each of the three comparisons. Yields of total phosphorus and nitrogen were higher during runoff conditions than non-runoff conditions in two of the three comparisons. Yields of nitrate plus nitrite, alkalinity, and chloride were affected less by contributions from storm runoff than by contributions from point sources and ground-water discharge; yields were similar during runoff and non-runoff conditions in two of the three comparisons.

At all stations on the Musconetcong River (M1, M2, M3, and M4), yields of total nitrogen, alkalinity, and chloride were affected more by contributions from storm runoff than by contributions from point sources (where present) and groundwater discharge; yields were higher during runoff conditions than non-runoff conditions in each of the three comparisons. Yields of fecal-coliform bacteria at stations M1, M2, and M3 and total phosphorus at stations M1, M3, and M4 were affected less by contributions from storm runoff than by contributions from point sources and ground-water discharge; yields during runoff and non-runoff conditions were similar in all three comparisons of fecal-coliform bacteria and in two of the three comparisons of total phosphorus yields. Yields of fecal-coliform bacteria were affected less by contributions from storm runoff than by contributions from point sources and ground-water discharge at station M4 (yields were similar during runoff and non-runoff conditions in two of the three comparisons). Yields of total phosphorus were affected more by contributions from storm runoff than by contributions from point sources and ground-water discharge at station M2 (yields were higher during runoff conditions than non-runoff conditions in all three comparisons). Yields of nitrate plus nitrite were affected more by contributions from storm runoff than by contributions from point sources and ground-water discharge at stations M3 and M4 (yields were higher during runoff conditions than non-runoff conditions in each of the three comparisons), and most likely were affected more by contributions from storm runoff than by contributions from point sources and ground-water discharge at station M2 (yields were higher during runoff conditions than non-runoff conditions in two of the three comparisons). Yields of nitrate plus nitrite were affected less by contributions from storm runoff than by contributions from point sources and ground-water discharge at station M1 (yields were similar during runoff and non-runoff conditions in two of the three comparisons).

At the station on the Whippany River, yields of most water-quality constituents were affected more by contributions from storm runoff than by contributions from point sources and ground-water discharge. Yields of total nitrogen, nitrate plus nitrite, fecal-coliform bacteria, alkalinity, and chloride were higher during runoff conditions than non-runoff conditions in each of the three comparisons. Yields of total phosphorus were higher during runoff conditions than non-runoff conditions in two of the three comparisons.

At the station on the Saddle River, yields of alkalinity and chloride were affected more by contributions from storm runoff than by contributions from point sources and ground-water discharge; yields were higher during runoff conditions than non-runoff conditions in each of the three comparisons. Yields of total nitrogen and nitrate plus nitrite most likely were affected more by contributions from storm runoff than by contributions from point sources and ground-water discharge; yields were higher during runoff conditions than non-runoff conditions in two of the three comparisons. Yields of total phosphorus and fecal-coliform bacteria were affected less by contributions from storm runoff than by contributions from point sources and ground-water discharge. Yields of total 
phosphorus were similar during runoff and nonrunoff conditions in each of the three comparisons, and yields of fecal-coliform bacteria were similar during runoff and non-runoff conditions in two of the three comparisons. Point-source sewage-treatment plants are located upstream from the station on the Saddle River and affect streamflow in the river.

\section{SUMMARY}

Historical water-quality data collected during 1982-97 during various streamflow conditions at eight stations on five streams in northern New Jersey--Flat Brook and Delaware, Musconetcong, Whippany, and Saddle Rivers--were evaluated by the U.S. Geological Survey, in cooperation with the Delaware River Basin Commission, to determine relations between water-quality and streamflow characteristics for watersheds of various sizes and with various amounts of land development. Relations between concentration and streamflow are difficult to evaluate because contributions from storm runoff are flow dependent--a low concentration can represent a high instream load during high-flow conditions. Yields (loads normalized to the basin area) determined for different stations are directly comparable. Results from the Tukey and Kruskal-Wallis statistical tests were used to determine differences in concentrations and yields during various streamflow conditions among the stations, and differences in concentrations and yields (1) during base flow and stormflow; (2) before, during, and after a storm; and (3) during low, medium, and high flows at each station.

Concentrations and yields of total phosphorus, nitrogen, nitrate plus nitrite, fecal-coliform bacteria, alkalinity, and chloride, and values of $\mathrm{pH}$ and specific conductance differed among the eight water-quality stations during eight various flow conditions. Streamflow condition was assigned to one of eight categories at the time of sample collection. The general pattern of differences in concentrations and yields among the stations was similar during each streamflow condition. Values were higher at stations on streams that drain areas with substantial development, such as those on the Saddle and Whippany Rivers and the upstream reach of the Musconetcong River, than at stations on streams that drain areas with little development, such as those on the Delaware River, Flat Brook, and the downstream reach of the Musconetcong River.

The streamflow condition can greatly affect the quantity of constituents transported by the stream. For constituents contributed to a stream by storm runoff, instream concentrations might remain constant, or increase or decrease slightly during runoff conditions (stormflows, during a storm, and high flows), but loads are higher during runoff conditions than non-runoff conditions (base flows, before a storm, and low flows). For constituents contributed to a stream from point sources and ground-water discharge, contributions most likely remain constant during runoff conditions, but concentrations and the percentage of total instream load from these sources are reduced.

Instream loads of water-quality constituents are affected more by contributions from storm runoff than by contributions from point sources and ground-water discharge in streams where yields are higher during runoff conditions (stormflow or a storm) than non-runoff conditions (base flow or before a storm). In such cases, concentrations during runoff conditions might be higher than during non-runoff conditions. Instream loads of water-quality constituents are affected less by contributions from storm runoff than by contributions from point sources and ground-water discharge in streams where yields during runoff conditions are equal to or lower than non-runoff conditions. In such cases, concentrations would be lower during runoff conditions than during non-runoff conditions. Storm runoff could be an important contributor of selected water-quality constituents to streams even when concentrations during stormflow and storms are lower than during base flow, before a storm, or after a storm because the river could be transporting higher masses (that is, total amounts) of constituents in the high streamflows associated with storm runoff.

To determine the relative importance of contributions of water-quality constituents from storm runoff and from point sources and groundwater discharge at the eight stations, differences 
were determined among yields (1) during base flow and storm flow; (2) before, during, and after a storm; and (3) during low, medium, and high flows at each station. Runoff conditions were considered to occur during stormflow, during a storm, and during high flows. Likewise, non-runoff conditions were considered to occur during base flow, before a storm, and during low flows.

If yields were significantly higher during runoff conditions than during non-runoff conditions in all three comparisons, indicating that the loads carried by the streams increased during runoff conditions, then yields were considered to be affected more by contributions from storm runoff than by contributions from point sources and ground-water discharge. If yields were significantly higher during runoff conditions than during non-runoff conditions in two of the three comparisons, then yields were considered most likely to be affected more by contributions from storm runoff than by contributions from point sources and ground-water discharge. If yields were similar during runoff and non-runoff conditions in two or all of the three comparisons, indicating that the loads in the streams were relatively constant during runoff conditions, then yields were considered to be affected less by contributions from storm runoff than by contributions from point sources and ground-water discharge.

Yields of total phosphorus were higher during runoff conditions than during non-runoff conditions at the station on the Flat Brook and the station on the Musconetcong River at Beattystown in a comparison of values (1) during base flow and stormflow; (2) before, during, and after a storm; and (3) during low, medium, and high flows. Therefore, at these two stations, yields of total phosphorus were affected more by contributions from storm runoff than by contributions from point sources and ground-water discharge.

Yields of total phosphorus were higher during runoff conditions than during non-runoff conditions at the station on the Delaware River in a comparison of values during (1) base flow and stormflow and (2) low, medium, and high flows, and at the station on the Whippany River in a comparison of values (1) before, during, and after a storm and (2) during low, medium, and high flows. Therefore, at these two stations, yields of total phosphorus most likely were affected more by contributions from storm runoff than by contributions from point sources and ground-water discharge.

Yields of total phosphorus were similar during runoff and non-runoff conditions at the most upstream and two most downstream stations on the Musconetcong River in a comparison of yields (1) during base flow and stormflow and (2) before, during, and after a storm, and at the station on the Saddle River in a comparison of yields (1) during base flow and stormflow; (2) before, during, and after a storm; and (3) during low, medium, and high flows. At these four stations, yields of total phosphorus were affected less by contributions from storm runoff than by contributions from point sources and ground-water discharge. Point-source discharge from sewage-treatment plants occurs upstream from the stations on the Saddle and Musconetcong Rivers.

Yields of total nitrogen were higher during runoff conditions than during non-runoff conditions at all stations on the Flat Brook and the Musconetcong and Whippany Rivers in a comparison of yields (1) during stormflow and base flow; (2) before, during, and after a storm; and (3) during low, medium, and high flows. Therefore, at these stations, yields of total nitrogen were affected more by contributions from storm runoff than by contributions from point sources and ground-water discharge.

Yields of total nitrogen were higher during runoff conditions than during non-runoff conditions at stations on the Delaware and Saddle Rivers in a comparison of yields (1) during base flow and stormflow and (2) during low, medium, and high flows. At these stations, yields of total nitrogen most likely were affected more by contributions from storm runoff than by contributions from point sources and ground-water discharge.

Yields of nitrate plus nitrite were significantly higher during runoff conditions than nonrunoff conditions at the stations on the Flat Brook and the Whippany River, and the two most downstream stations on the Musconetcong River in a 
comparison of yields (1) during base flow and stormflow; (2) before, during, and after a storm; and (3) during low, medium, and high flows. At these stations, yields of nitrate plus nitrite were affected more by contributions from storm runoff than by contributions from point sources and ground-water discharge. Yields of nitrate plus nitrite were significantly higher during runoff conditions than non-runoff conditions at the station on the Musconetcong River at Beattystown in a comparison of yields (1) during base flow and stormflow and (2) before, during, and after a storm and at the station on the Saddle River in a comparison of yields during (1) base flow and stormflow and (2) low, medium, and high flows. At these two stations, the yields of nitrate plus nitrite most likely were affected more by contributions from storm runoff than by contributions from point sources and ground-water discharge.

Yields of nitrate plus nitrite at the station on the Delaware River and the most upstream station on the Musconetcong River were similar during runoff and non-runoff conditions in a comparison of yields (1) during base flow and stormflow and (2) before, during, and after a storm. Yields of nitrate plus nitrite at these stations were affected less by contributions from storm runoff than by contributions from point sources and ground-water discharge.

Yields of bacteria were significantly higher during runoff conditions than non-runoff conditions at all stations on the Flat Brook and the Delaware and Whippany Rivers in a comparison of yields (1) during stormflow and base flow; (2) before, during, and after a storm; and (3) during low, medium, and high flows. Yields of fecalcoliform bacteria at these stations were affected more by contributions from storm runoff than by contributions from point sources and ground-water discharge.

Yields of bacteria were similar during runoff and non-runoff conditions at the three upstream stations on the Musconetcong River in a comparison of yields (1) during stormflow and base flow; (2) before, during, and after a storm; and (3) during low, medium, and high flows; at the most downstream station on the Musconetcong River in a comparison of yields during (1) base flow and stormflow and (2) low, medium, and high flows; and at the station on the Saddle River in a comparisons of yields (1) before, during, and after a storm and (2) during low, medium, and high flows. Yields of bacteria at these five stations were affected less by contributions from storm runoff than by contributions from point sources and ground-water discharge.

Yields of alkalinity were significantly higher during runoff conditions than non-runoff conditions at all stations on the Musconetcong, Whippany, and Saddle Rivers in a comparison of yields (1) during stormflow and base flow; (2) before, during, and after a storm; and (3) during low, medium, and high flows. At these stations, yields of alkalinity were affected more by contributions from storm runoff than by contributions from point sources and ground-water discharge. Yields of alkalinity were significantly higher during runoff conditions than non-runoff conditions at the station on Flat Brook in a comparison of yields during (1) base flow and stormflow and (2) low, medium, and high flows. At this station on the Flat Brook, yields of alkalinity most likely were affected more by contributions from storm runoff than by contributions from point sources and ground-water discharge. At the station on the Delaware River, yields of alkalinity were similar (1) during stormflow and base flow and (2) before, during, and after a storm, indicating that yields were affected less by contributions from storm runoff than by contributions from point sources and ground-water discharge.

Contributions of $\mathrm{pH}$ from storm runoff were not significant for all the streams studied because the $\mathrm{pH}$ varied little during changing streamflow. Although alkalinity decreased in these streams during stormflow, the buffering capacity in the river water was sufficient to minimize any change in the $\mathrm{pH}$ from the runoff at all stations on the Musconetcong, Whippany, and Saddle Rivers.

Yields of chloride were significantly higher during runoff conditions than non-runoff conditions at all stations on the Flat Brook, and the Musconetcong, Whippany, and Saddle Rivers in a comparison of yields (1) during stormflow and base flow; (2) before, during, and after a storm; and 
(3) during low, medium, and high flows. At these stations the yields of chloride were affected more by contributions from storm runoff than by contributions from point sources and ground-water discharge. At the station on the Delaware River, yields of chloride were similar (1) during stormflow and base flow and (2) before, during, and after a storm, indicating that yields at this station were affected less by contributions from storm runoff than by contributions from point sources and ground-water discharge. Storm runoff significantly reduced the specific conductance in all streams in the study area. Specific conductance was significantly lower after a storm than before or during the storm. 


\section{REFERENCES CITED}

Albert, Richard, and Limbeck, Robert, 2000, High flow management objectives for New Jersey non-coastal waters: A study of the Delaware, Saddle, Whippany, and Musconetcong Rivers and Flat Brook: West Trenton, N.J., Delaware River Basin Commission, $34 \mathrm{p}$.

Ayers, M.A., and Pustay, E.A., 1988, New Jersey ground-water quality, in U.S. Geological Survey, National Water Summary 1986-hydrologic events and ground-water quality: U.S. Geological Survey Water-Supply Paper 2325, p. 369-376.

Buxton, D.E., Hunchak-Kariouk, Kathryn, and Hickman, R.E., 1998, Relations of surfacewater quality to streamflow in the Hackensack, Passaic, Elizabeth, and Rahway River Basins, New Jersey and vicinity, water years 1976-93: U.S. Geological Survey WaterResources Investigations Report 98-4049, $102 \mathrm{p}$.

Buxton, D.E., Hunchak-Kariouk, Kathryn, and Hickman, R.E., 1999, Relations of surfacewater quality to streamflow in the Wallkill and Upper Delaware River Basins, New Jersey and vicinity, water years 1976-93: U.S. Geological Survey Water-Resources Investigations Report 99-4016, 97 p.

Eaton, A.D., Clesceri, L.S., and Greenberg, A.E., ed., 1995, Standard methods for the examination of water and wastewater (19th ed.): Washington, D.C., American Public Health Association, $948 \mathrm{p}$.

Fenneman, N.M., 1938, Physiography of the eastern United States: New York, McGraw-Hill Book Company, 714 p.
Harding, J.S., Benfield, H.E., Bolstad, P.V., Helfman, G.S., and Jones III, E.B.D., 1998, Stream biodiversity: The ghost of land use past: Proceedings of the National Academy of Sciences, v. 95, December, p. 1484314847.

Hay, L.E., and Campbell, J.P., 1990, Water-quality trends in New Jersey streams: U.S. Geological Survey Water-Resources Investigations Report 90-4046, 297 p.

Helsel, D.R., and Hirsch, R.M., 1992, Statistical methods in water resources: New York, Elsevier Science Publishing Company, $522 \mathrm{p}$.

Hem, J.D., 1985, Study and interpretation of the chemical characteristics of natural water: U.S. Gelogical Survey Water-Supply Paper 2254, 263 p.

Hickman, R.E., and Barringer, T.H., 1999, Trends in water quality of New Jersey streams, water years 1986-95: U.S. Geological Survey Water-Resources Investigations Report 98-4204, 174 p.

Hirsch, R.M., 1982, A comparison of four streamflow record extension techniques: Water Resources Research, v. 18, no. 18, p. 10811088.

Hutchinson, N.E., 1975, WATSTORE: National Water Data Storage and Retrieval System: user's guide: U.S. Geological Survey OpenFile Report 75-426, 791 p.

Johnsson, P.A., and Barringer, J.L., 1993, Water quality and hydrogeochemical processes in McDonalds Branch Basin, New Jeresy Pinelands, 1984-88: U.S. Geological Survey Water-Resources Investigations Report 91-4081, $111 \mathrm{p}$. 


\section{REFERENCES CITED--CONTINUED}

New Jersey Department of Environmental Protection, 1998, Surface water quality standards: N.J.A.C. 7:9B: Trenton, N.J., New Jersey Department of Environmental Protection, Office of Environmental Planning, 122 p.

Price, C.V., and Schaefer, F.L., 1995, Estimated loads of selected constituents from permitted and nonpermitted soures at selected surfacewater-quality stations in the Musconetcong, Rockaway, and Whippany River Basins, New Jersey, 1985-90: U.S. Geological Survey Water-Resources Investigations Report 95-4040, $28 \mathrm{p}$.

Rosgen, Dave, 1996, Applied river morphology: Pagosa Springs, Co., Wildland Hydrology Books, 390 p.

Sawyer, C.N., and McCarty, P.L., 1978, Chemistry for environmental engineering: New York, McGraw-Hill Inc., 532 p.

Searcy, J.K., 1959, Flow-duration curves: U.S. Geological Survey Water-Supply Paper 1542-A, 33 p.

Stackelberg, P.E., Hopple, J.A., and Kauffman, L.J., 1997, Occurrence of nitrate, pesticides, and volatile organic compounds in the Kirkwood-Cohansey aquifer system, southern New Jersey: U.S. Geological Survey WaterResources Investigations Report 97- 4241, 8 p.

Szabo, Zoltan, Rice, D.E., Ivahnenko, Tamara, and Vowinkel, E.F., 1994, Delineation of the distribution of pesticides and nitrate in an unconfined aquifer in the New Jersey Coastal Plain by flow path analysis, in Weigmann, D.L., ed., New directions in pesticide research development, management, and policy, Fourth National Pesticide Conference, Virginia Water Resources Research Center, Virginia Polytechnic University, Blacksburg, Va., p. 100-119. 